\title{
History of the Middle Berriasian transgression on the Jura carbonate platform: revealed by high-resolution sequence- and cyclostratigraphy (Switzerland and France)
}

\author{
Jonas Tresch · André Strasser
}

Received: 8 January 2008/Accepted: 27 September 2008/Published online: 2 December 2008

(C) Springer-Verlag 2008

\begin{abstract}
The Middle Berriasian deposits of the Jura platform in Switzerland and France have already been well studied in terms of high-resolution sequence stratigraphy and different orders of depositional sequences (large-, medium-, and small-scale) have been defined. The hierarchical stacking pattern of the sequences and the time span represented by the investigated interval imply that sea-level fluctuations in the Milankovitch frequency band as well as differential subsidence caused the observed changes of accommodation on the Jura platform. The present study focuses on three small-scale sequences within the transgressive interval of a large-scale sequence. The initial flooding of the platform is marked by a facies change from supra- and intertidal (Goldberg Formation) to shallowmarine subtidal deposits (Pierre Châtel Formation). Detailed logging and facies analysis of 11 sections allow recognizing small environmental changes that define elementary sequences within the well-established small-scale sequences and distinguishing between autocyclic and allocyclic processes in sequence formation. It is concluded that the small-scale sequences correspond to the 100-ka orbital eccentricity cycle, while allocyclic elementary sequences formed in tune with the 20-ka precession cycle. Based on the correlation of elementary and small-scale sequences it can be shown that the Jura platform has been flooded stepwise by repeated transgressive pulses. Differential
\end{abstract}

J. Tresch $(\bowtie) \cdot$ A. Strasser

Department of Geosciences, University of Fribourg,

Chemin du Musée 6, 1700 Fribourg, Switzerland

e-mail: treschj@gmx.ch

Present Address:

J. Tresch

Dr. M. Kobel + Partner AG, Büro für Technische Geologie,

Grossfeldstrasse 74, 7320 Sargans, Switzerland subsidence and pre-existing platform morphology further controlled sediment accumulation and distribution during the transgression. The combination of high-resolution sequence stratigraphy and cyclostratigraphy then enables the reconstruction of hypothetical palaeogeographic maps in time increments of a few ten thousand years.

Keywords Berriasian - Jura carbonate platform · High-resolution correlations - Sequence stratigraphy · Cyclostratigraphy · Transgression · Allocyclicity . Autocyclicity

\section{Introduction}

Berriasian sections on the Jura platform have been well investigated in terms of high-resolution sequence- and cyclostratigraphy (Strasser 1988; Waehry 1989; Strasser 1994; Pasquier 1995; Pasquier and Strasser 1997; Strasser and Hillgärtner 1998; Hillgärtner 1999; Hillgärtner and Strasser 2003; Strasser et al. 2004; Rameil 2005). This study now focuses on the recognition and interpretation of elementary sequences, the smallest building blocks of the sedimentary record. The Middle Berriasian transgressive interval has been chosen because, in combination with subsidence, transgression creates accommodation space, and the best chance to preserve sediments on shallowmarine carbonate platforms and to obtain a relatively complete sedimentary succession is during increasing accommodation space.

According to the sequence-stratigraphic interpretations of Pasquier and Strasser (1997) and Hillgärtner (1999), the investigated transgressive interval is part of a large-scale sequence, which lies between sequence boundaries Be 4 and Be5 as defined in the sequence-chronostratigraphic chart of 
Hardenbol et al. (1998). According to these studies, the large-scale sequence is composed of medium-scale and small-scale sequences. These sequences can be correlated from section to section along the Jura platform without any problems. The time interval represented by the sedimentary rocks and the stacking pattern of the depositional sequences between the large-scale sequence boundaries $\mathrm{Be} 4$ and $\mathrm{Be} 5$ reveal that sedimentation has at least partly been controlled by orbital (Milankovitch) cycles (Pasquier and Strasser 1997; Strasser and Hillgärtner 1998; Hillgärtner 1999; Strasser et al. 2004). The medium-scale sequences correspond to the long eccentricity cycle (400 ka) whereas smallscale sequences have been deposited in tune with the short eccentricity cycle (100 ka; Berger et al. 1989); however, the interpretation of elementary sequences (the smallest units of the sedimentary record where facies evolution indicates an environmental cycle) is not straightforward. On shallow carbonate platforms, allocyclic signals such as eustatic sealevel fluctuations may be overruled by autocyclic processes such as lateral migration of sediment bodies (Strasser 1991; Hillgärtner 1999). Autocyclic processes thus may create sedimentary sequences similar to those formed by allocyclic control. Moreover, if low-amplitude sea-level changes did not produce facies contrasts in subtidal environments and thus were not recorded, or if subaerial exposure precluded sediment deposition ("missed beats" sensu Goldhammer et al. 1990), the sequence- and cyclostratigraphic interpretation will be complicated.

Detailed facies analysis is, therefore, needed in order to document the subtle facies changes observed on shallow carbonate platforms. Such changes can at least partly be related to relative sea-level changes and, hence, be interpreted in terms of sequence stratigraphy. Their diagnostic intervals and surfaces (sequence boundaries, transgressive surfaces and/or maximum floodings) can commonly be correlated between the studied sections. The correlation over long distances and the observed stacking pattern are used as criteria to distinguish allo- from autocyclic sedimentary successions. Autocyclic deposits are of local extension and, therefore, cannot be correlated between sections. However, intervals containing autocyclically formed depositional sequences can at least be delimited at their base and top by sequence-stratigraphic correlations of allocyclic deposits. It is assumed that elementary sequences have been deposited in tune with orbital precession cycles of $20 \mathrm{ka}$ because, on average, one small-scale sequence is composed of five elementary sequences (Strasser et al. 1999, 2004; Tresch 2007).

It is the goal of this study to monitor the Middle Berriasian flooding of the Jura platform in time and space with a time resolution of a few ten thousand years, with the help of the high-resolution sequence-stratigraphic correlation framework in combination with the cyclostratigraphic interpretation. Additionally, the controlling factors that steered this flooding are evaluated. It will be shown that not only eustatic sea-level fluctuations but also pre-existing platform morphology, irregular sediment distribution, and differential subsidence played important roles in the making of the sedimentary record.

\section{Geographic and palaeogeographic setting}

The studied sections are all located in the central and southern Jura Mountains of Switzerland and France (Fig. 1). The Jura is a relatively young mountain chain formed during a late Alpine phase (Miocene and Pliocene). It mainly consists of Mesozoic sedimentary rocks, which have been detached from their substratum along incompetent members of Triassic formations (e.g., Trümpy 1980). The studied sections are located in the "Folded Jura", which is characterized by a succession of anti- and synclines with more or less NE-SW-oriented axes.

The predominantly shallow-marine sediments have been deposited on a platform along a passive continental margin. During the Berriasian, this platform was never far from exposure with maximum water depths of a few tens of meters (Hillgärtner 1999). The Jura platform was located at the northern margin of the Ligurian Tethys and made up the central part of the North-Tethys platform (Fig. 2). It corresponds to the continuation of the southeastern part of the Paris basin (Arnaud 1988). During the Berriasian, continental areas surrounded the Jura platform: to the north the Rhenish-Bohemian Massif and to the west the Armorican and the Central massifs (e.g., Ziegler 1988; Détraz and Mojon 1989; Thierry and Barrier 2000; Guillocheau et al. 2000). Siliciclastics found on the Jura platform mainly derived from these land areas. The Helvetic shelf represents the western and southern continuation of the North-Tethys platform, including the Delphino-Helvetic shelf to the southwest (Détraz and Mojon 1989). This realm consists of carbonates and siliciclastics derived from the northern continental areas. The average subsidence rate of the NorthTethyan margin generally increased from north (Jura platform) to south (Helvetic shelf) and was in the range of 1$7 \mathrm{~m} / 100 \mathrm{ka}$ (Wildi et al. 1989).

A well-dated basinal section of the Vocontian basin, the Montclus section, has been integrated into the correlation scheme in order to improve the biostratigraphic control on the Jura platform. The Vocontian basin was the southwestern continuation of the Ligurian Tethys (Fig. 2). It was delimited to the north and west by the Helvetic shelf, the Jura platform, and the landmass of the Massif Central. This basin has been filled with hemipelagic to pelagic sediments (carbonates and siliciclastics) and intermittent biodetrital influx from the surrounding platforms (e.g., Strohmenger and Strasser 1993). 
Fig. 1 Location of the studied sections in the central and southern Jura Mountains (Switzerland and France) and the Vocontian basin (France)

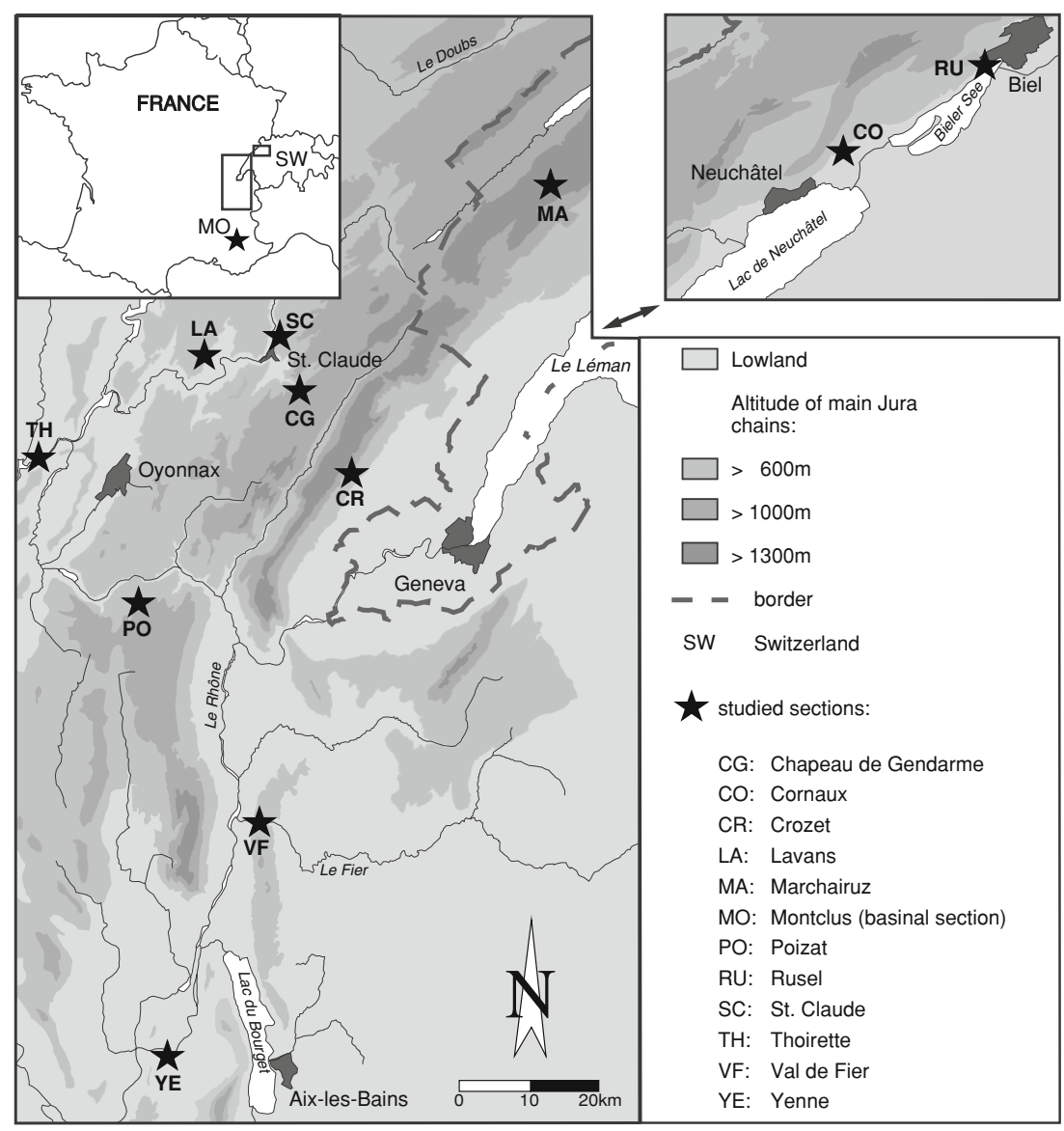

Fig. 2 Palaeogeographic position of the Jura platform based on the map of Thierry and Barrier (2000). Modified for the Berriasian according to Curnelle and Dubois (1986), Arnaud (1988), and Guillocheau et al. (2000)
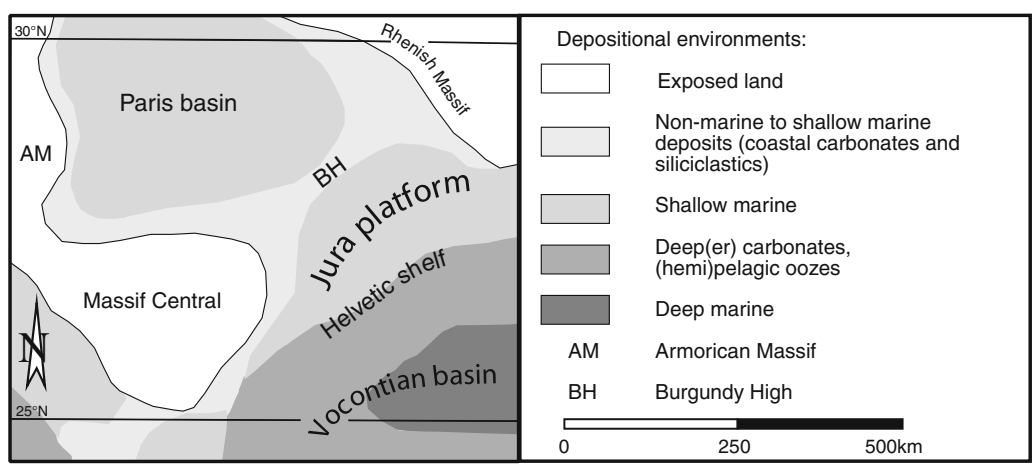

\section{Lithostratigraphic and biostratigraphic framework}

The lower part of the studied sections has commonly been termed "Purbeckian". This appellation refers to the characteristic succession of peritidal deposits (containing charophytes, black pebbles, and locally evaporite pseudomorphs) resembling the "Purbeck Beds" sensu anglico (e.g., Carozzi 1948; Häfeli 1966; Ainardi 1977; Strasser 1988). In order to avoid any confusion, this succession is referred to as Goldberg Formation (Fig. 3) according to the lithostratigraphic definition of Häfeli (1966). A succession of massive beds with shallow-marine facies marks the Middle Berriasian transgressive interval overlying the top of the Goldberg Formation. These characteristic beds can easily be recognized in the field because of their resistance to weathering. They belong to the Pierre Châtel Formation according to the definition of Steinhauser and Lombard (1969). The overlying Vions Formation (also defined by Steinhauser and Lombard 1969) contains mainly shallow-marine facies with some lacustrine and palustrine intervals. Moreover, the sedimentary rocks of the Vions Formation are characterized by a remarkable increase of detrital quartz and clay (Pasquier 1995; Hillgärtner 1999). 


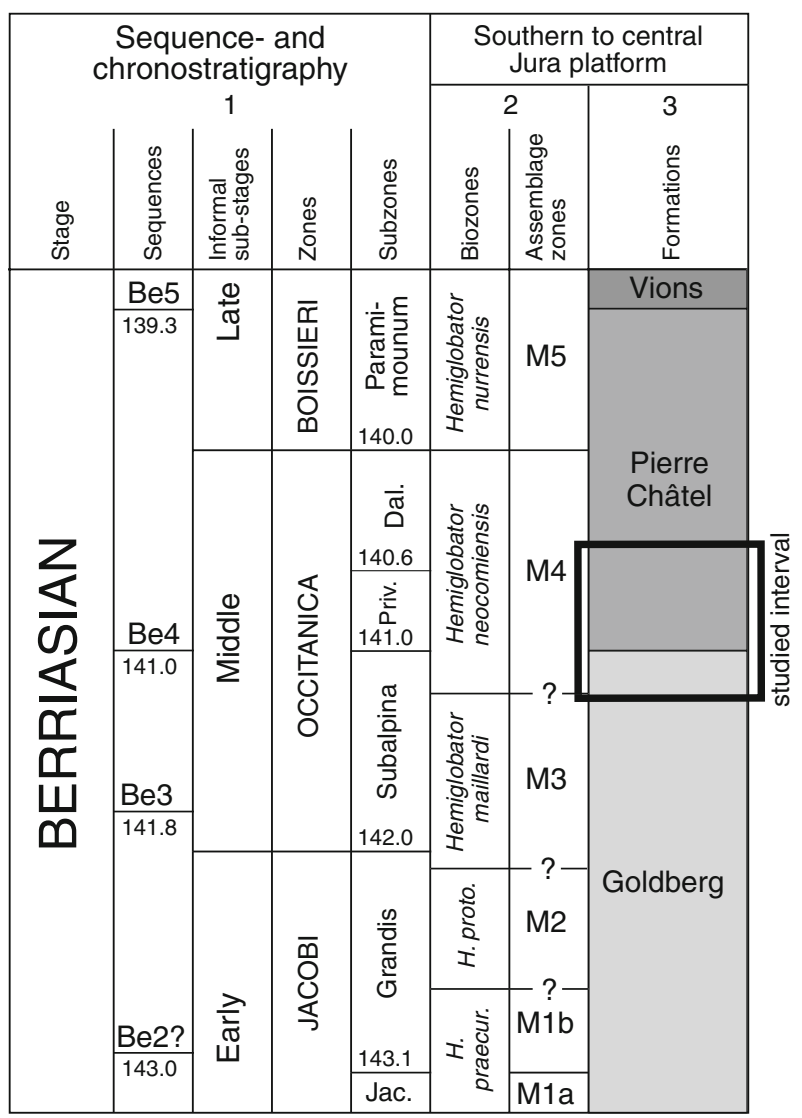

1 Sequence-, bio- and chronostratigraphic framework (Ages in Ma; Hardenbol et al. 1998)

2 Charophyte biozonation and charopyte-ostracode assemblage zones (Mojon 2002)

3 Chronostratigraphic positions of formations based on Pasquier (1995), Hillgärtner (1999), Strasser et al. (2004), and Tresch (2007)

Dal.: Dalmasi

Priv.: Privasensis

Jac.: Jacobi

Fig. 3 Comparison of the sequence-chronostratigraphic chart (Hardenbol et al. 1998) with the bio- and lithostratigraphy published for the Jura platform

Dating of these formations is difficult because biostratigraphically relevant fossils (e.g., ammonites) are rare on the Jura platform. According to Clavel et al. (1986) and Waehry (1989), the base of the Pierre Châtel Formation lies in the Privasensis ammonite subzone (Fig. 3). The limit between the Pierre Châtel Formation and the Vions Formation lies in the Paramimounum ammonite subzone (Clavel et al. 1986). The Vions Formation has been dated by the benthic foraminifers Pavlovecina allobrogensis and Pseudotextulariella courtionensis, which are attributed to the Paramimounum ammonite subzone (Clavel et al. 1986).

In addition, the top of the Goldberg Formation and the base of the Pierre Châtel Formation have been dated by charophyte-ostracode assemblages (Mojon 2002). Charophytes of the genus Hemiglobator have been widely used for dating Berriasian sedimentary rocks (Mojon and
Fig. 4 Best-fit correlation of the large-scale sequence between sequence boundaries $\mathrm{Be} 4$ and $\mathrm{Be} 5$ (according to Hardenbol et al. 1998) and its medium- and small-scale sequences of the Jura platform and the Vocontian basin. While sediments accumulated in the basin during lowstand conditions (LD), most of the Jura platform was subjected to emersion. Note that the limits between ammonite subzones and calpionellid zones are approximate. Charophyte assemblages in parentheses are reworked. For legend of symbols refer to Fig. 6

Strasser 1987; Martín-Closas and Serra-Kiel 1991; Riveline et al. 1996). Berriasian deposits have also been dated by ostracodes of the genus Cypridea (Anderson and Bazley 1971; Anderson 1985; Keen 1993; Horne 1995, 2002). Mojon (2002) combined charophyte and ostracode biozonations based on samples from sections of the Jura platform. According to the biozonation of Mojon (2002), the top of the Goldberg Formation is in the range of assemblage zones M1b to M4. The base of the Pierre Châtel Formation lies in assemblage zone M4 and in some sections contains reworked species of assemblage zone M3 (Fig. 3).

\section{Sequence- and cyclostratigraphic framework}

Pasquier (1995), Hillgärtner (1999), and Tresch (2007) have published detailed sequence-stratigraphic correlations of Berriasian sections from the Jura platform. As an example, a correlation scheme for two platform sections (Rusel and Chapeau de Gendarme) and a section from the Vocontian basin (Montclus) is illustrated in Fig. 4. According to the biostratigraphy and the high-resolution sequential framework (Strasser and Hillgärtner 1998; Hillgärtner 1999; Strasser et al. 2004) (Fig. 3), the transgressive surface at the base of the Pierre Châtel Formation lies between two largescale sequence-boundary intervals, which correspond to the sequence boundaries Be4 and Be5 of the sequence-chronostratigraphic chart of Hardenbol et al. (1998).

The top of the Goldberg Formation has been interpreted as sequence boundary Be4 (Strasser and Hillgärtner 1998; Hillgärtner 1999; Strasser et al. 2004). This interval is characterized by recurrent emersion horizons (containing, e.g., birdseyes, desiccation cracks, karst surfaces). Additionally, the dating by charophyte-ostracode assemblages (Mojon 2002) reveals that the upper part of the Goldberg Formation lies in the range of sequence boundaries $\mathrm{Be} 2$ to Be4 (Grandis to Privasensis ammonite subzones; Fig. 3). This indicates prolonged emersion, non-deposition, and condensation during this time interval. The base of the Pierre Châtel Formation is marked by a sharp transgressive surface (TS in Fig. 4). The facies evolution within this formation indicates periodic deepening and shallowing of depositional environments and/or suggests that the environmental conditions changed from restricted marine to open marine and back to restricted (Waehry 1989; Pasquier 


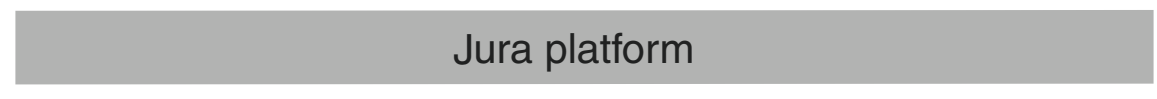

Rusel

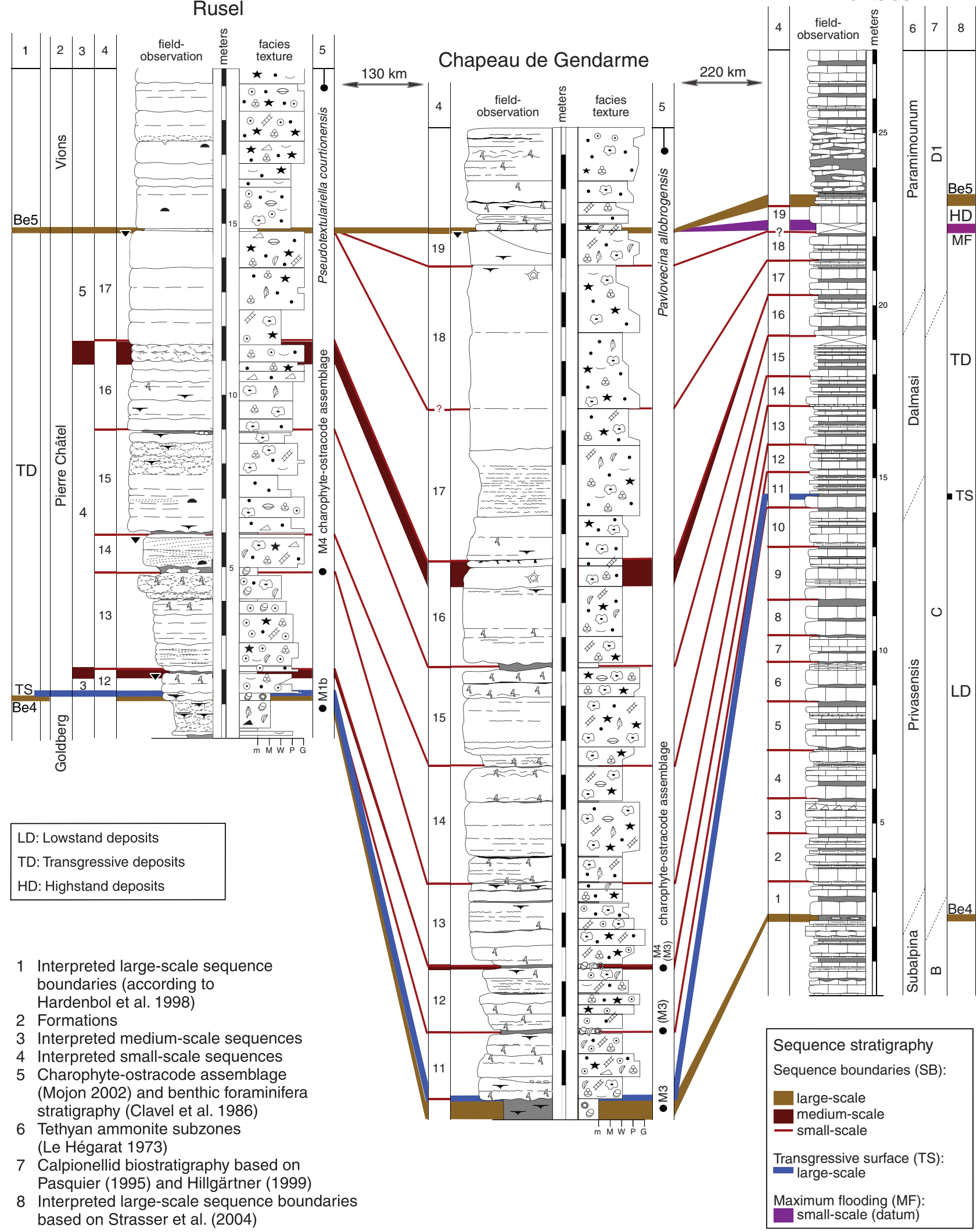


1995; Hillgärtner 1999; Strasser et al. 2004; Tresch 2007). The stratigraphic succession of depositional environments, diagnostic surfaces, and the stacking pattern of beds recorded in the investigated sections are organized hierarchically in several orders of depositional sequences. In most cases, the identification of depositional sequences on the level of medium- and small-scale sequences is easy due to well-developed facies contrasts (Fig. 4). Changes in carbonate productivity controlled by ecological factors and sediment distribution through currents and waves certainly influenced the sedimentary record, but the observed facies evolution is best explained by changes in relative sea level. The hierarchical stacking pattern of the sequences results from the superposition of different amplitudes and frequencies of sea-level fluctuations.

The thick transgressive deposits (TD) are characterized by relatively restricted facies and repeated subaerial exposure (karstification, e.g., Rusel section) in the platform interior and by open-lagoonal deposits in more distal platform positions (Tresch 2007). A transitional facies succession is displayed in the Chapeau de Gendarme section where relatively thin beds with restricted facies dominate at the base of the Pierre Châtel Formation. They gradually change to massive, open-lagoonal intervals in the overlying beds (Fig. 4).

The large-scale maximum-flooding interval has been used as datum for the lateral correlation of the sections. Maximum floodings are well suited for correlations over long distances because they have the best chance to homogenize a morphological relief in shallow-marine settings and, consequently, to be isochronous (Embry 2002; Sandulli and Raspini 2004). However, the sedimentary record of the large-scale maximum flooding of the Rusel and Chapeau de Gendarme sections has probably been truncated by karstification at the top of the Pierre Châtel Formation during the sea-level drop creating sequence boundary Be5 (Fig. 4). In other sections, this maximum flooding has been placed in the most open-marine facies. The transition from the Pierre Châtel to the Vions Formation is generally characterized by karst surfaces and/or palaeosols (Pasquier 1995; Pasquier and Strasser 1997; Hillgärtner 1999; Strasser et al. 2004), which reflect the low relative sea level at sequence boundary Be5. Hence, the large-scale highstand deposits (HD) are commonly strongly condensed and/or eroded and have only been recorded in some sections (e.g., Marchairuz section). As a consequence, the largescale sequence between the boundaries $\mathrm{Be} 4$ and $\mathrm{Be} 5$ displays an extremely asymmetric stacking pattern reflected by thick transgressive and thin highstand deposits (Fig. 4).

In order to improve the biostratigraphic control on the Jura platform, a section of the Vocontian basin, the Montclus section, has been integrated into the correlation framework (Fig. 4). This section is well dated by ammonites and calpionellids (Le Hégarat 1973; Jan du Chêne et al. 1993; Pasquier 1995; Hillgärtner 1999). The entire sedimentary record is composed of a succession of hemipelagic to pelagic marls and limestones. The sequence-stratigraphic interpretation generally follows that of Strasser et al. (2004).

The sequence-chronostratigraphic time-frame published by Hardenbol et al. (1998) is used as reference in this study. According to this, the large-scale sequence boundaries Be4 and Be5 are dated at 141.0 and at $139.3 \mathrm{Ma}$, respectively (Fig. 3). The time comprised between these two sequence boundaries is, therefore, in the range of 1.7 million years. In the Montclus section, which is assumed to be more or less complete, 16-20 small-scale sequences have been identified between sequence boundaries $\mathrm{Be} 4$ and $\mathrm{Be} 5$ (numbers vary according to interpretation: Pasquier and Strasser 1997; Hillgärtner 1999; Strasser et al. 2004). Dividing the 1.7 million years by 16 (numbers of smallscale sequences), one small-scale sequence represents a duration of $106 \mathrm{ka}$. This is close to the periodicity of the short orbital eccentricity cycle (100 ka).

Different studies use the hierarchical stacking of depositional sequences as a criterion for the influence of orbital forcing on deep- and shallow-marine carbonates (e.g., Goldhammer et al. 1990; Osleger and Read 1991; Schwarzacher 1993; Sadler 1994; Lehmann et al. 1998; Lehrmann and Goldhammer 1999; Raspini 2001; D'Argenio et al. 2004). A consistent 4:1 relationship (bundling) between small- and medium-scale sequences in the sedimentary rocks of the Pierre Châtel and the Vions Formations has been detected (e.g., Hillgärtner 1999; Strasser et al. 2004). Consequently, and in accordance with the biostratigraphic and sequence-chronostratigraphic timing, it is assumed that medium-scale sequences have been deposited in tune with the long eccentricity cycle of $400 \mathrm{ka}$. Small-scale sequences comprehend 3-6 elementary sequences in the Middle to Late Berriasian of the Jura platform (Pasquier 1995; Pasquier and Strasser 1997; Hillgärtner 1999; Strasser et al. 2004). On the average, five elementary sequences build up one small-scale sequence on the Jura platform. They most likely have been controlled by relative sea-level fluctuations in tune with the precession cycle. Shallowing-up sequences in Berriasian marginalmarine deposits have also been related to orbital cycles in the Dorset region of southern England (Anderson 2004a; Tresch 2007) and in the Prebetic zone of southern Spain (Jimenez de Cisnero and Vera 1993; Anderson 2004b).

\section{Materials and methods}

Eleven sections, which have already been well described and dated in the literature, have been relogged on a 
decimetric scale in the field (Fig. 1). The focus is set on four small-scale sequences and their elementary sequences at the base of the Pierre Châtel Formation (small-scale sequences $10-13$ in Figs. 4, 7-10). A total of 114 section meters has been logged and studied bed by bed. Weathering profile, lithology, and sedimentary structures have been determined in the field. Thin section analyses of 566 samples were carried out by light-optical microscope investigations in order to determine depositional facies (Tresch 2007). Etched slabs have been used to analyze larger constituents (e.g., oncoids and coral debris) and sedimentary structures. Additionally, 50 samples of marls were washed and sieved. The obtained fractions have been picked and analyzed under the binocular. On average, five samples per meter have been investigated for the sections of the Jura platform.

Facies evolution and the sequence-stratigraphic interpretation have been worked out in detail for all sections (Tresch 2007). In order to obtain a high-resolution sequential framework, diagnostic surfaces and intervals have been traced from section to section across the Jura platform. This correlation framework helps to delimit deposits, which have been controlled by autocyclic processes such as migrating tidal channels or shoals and to identify local and/or regional gaps in the sedimentary record. Based on the combination of the high-resolution sequential framework and the cyclostratigraphic interpretation, a time-space diagram of all investigated sections can then be constructed by assuming that an elementary sequence represents one precession cycle of $20 \mathrm{ka}$. In this diagram, sequence boundaries of small-scale and elementary sequences are considered to be time lines. The timespace diagram is used to monitor the Middle Berriasian transgression of the Jura platform in time steps of a few thousand years. Hypothetical palaeogeographic maps have been drawn in order to illustrate the flooding of the platform.

Facies analysis and model

For high-resolution sequence-stratigraphic interpretations, it is important to gather essential facies informations and to interpret them in terms of depositional environments. Especially on shallow carbonate platforms depositional processes create complex patterns of facies mosaics in time and space (e.g., Strasser and Samankassou 2003; Wright and Burgess 2005). The facies of the investigated sedimentary rocks have been attributed in a simplified manner to four depositional environments (Tresch 2007): (1) The continental environment is mainly characterized by the cooccurrence of charophyte stems and gyrogonites indicating freshwater ponds (e.g., Platt 1989; Flügel 2004). Commonly they are associated with ostracodes and gastropods.
In some intervals, charophyte stems are associated with pseudomorphs after halite, which is interpreted as being due to seasonally hypersaline conditions. (2) The tidal-flat environment is well defined by sedimentary structures such as birdseyes, lamination, desiccation cracks, and/or circumgranular cracks. Ostracodes are common and in some samples abundant. They are associated with some bivalves and gastropods. However, the faunal and floral diversity is strongly reduced or fossils are even absent in some beds ("stressed environment"; Pratt and James 1992). (3) The internal-lagoonal environment represents a shallow marine, low-energy basin, which is partly separated by a morphological barrier (e.g., shoal field) from the open lagoon. Normal marine conditions are indicated by a diverse fauna and flora (e.g., bivalves, gastropods, ostracodes, different species of foraminifers, and dasycladaceans). Moreover, an increased amount of stenohaline organisms (e.g., echinoderms and brachiopods) occurs in this depositional setting. Restricted conditions are locally indicated by a reduced diversity of the fauna and flora. The occurrence of monospecific dasyclad algae in combination with a euryhaline faunal association (e.g., bivalves, gastropods, and ostracodes) is attributed to a restricted, internal-lagoonal setting. Peloids and oncoids are common in internal lagoons whereas ooids (mainly radial and superficial) are concentrated in tidally influenced high-energy settings. (4) Openlagoonal sediments are characterized by an increase of stenohaline organisms relative to the amount of euryhaline ones. Additionally, some coral debris, sponges, and red algae contribute to a further increase of the faunal and floral diversity. Most of the samples interpreted as openlagoonal deposits contain large Bacinella-Lithocodium oncoids forming float- and rudstones (Hillgärtner 1999; Védrine et al. 2007; Tresch 2007).

Lateral transitions between depositional environments are common in shallow-marine systems and have to be taken into account. Based on the likely spatial distribution of the depositional environments, a conceptual depositional model has been constructed (Fig. 5). The model illustrates a static, time-independent shallow carbonate platform and the lateral arrangement of its depositional environments. The sedimentologic interpretation of the sections follows this depositional model (Tresch 2007). The facies succession in a section is then interpreted in terms of sequence stratigraphy, following the methodology proposed by Strasser et al. (1999).

Interpretation of sections

The St. Claude (Figs. 7, 8) and the Lavans sections (Figs. 9, 10) have been chosen in order to illustrate how the investigated sections have been interpreted in terms of facies and sequence analysis (for symbols refer to Fig. 6). 

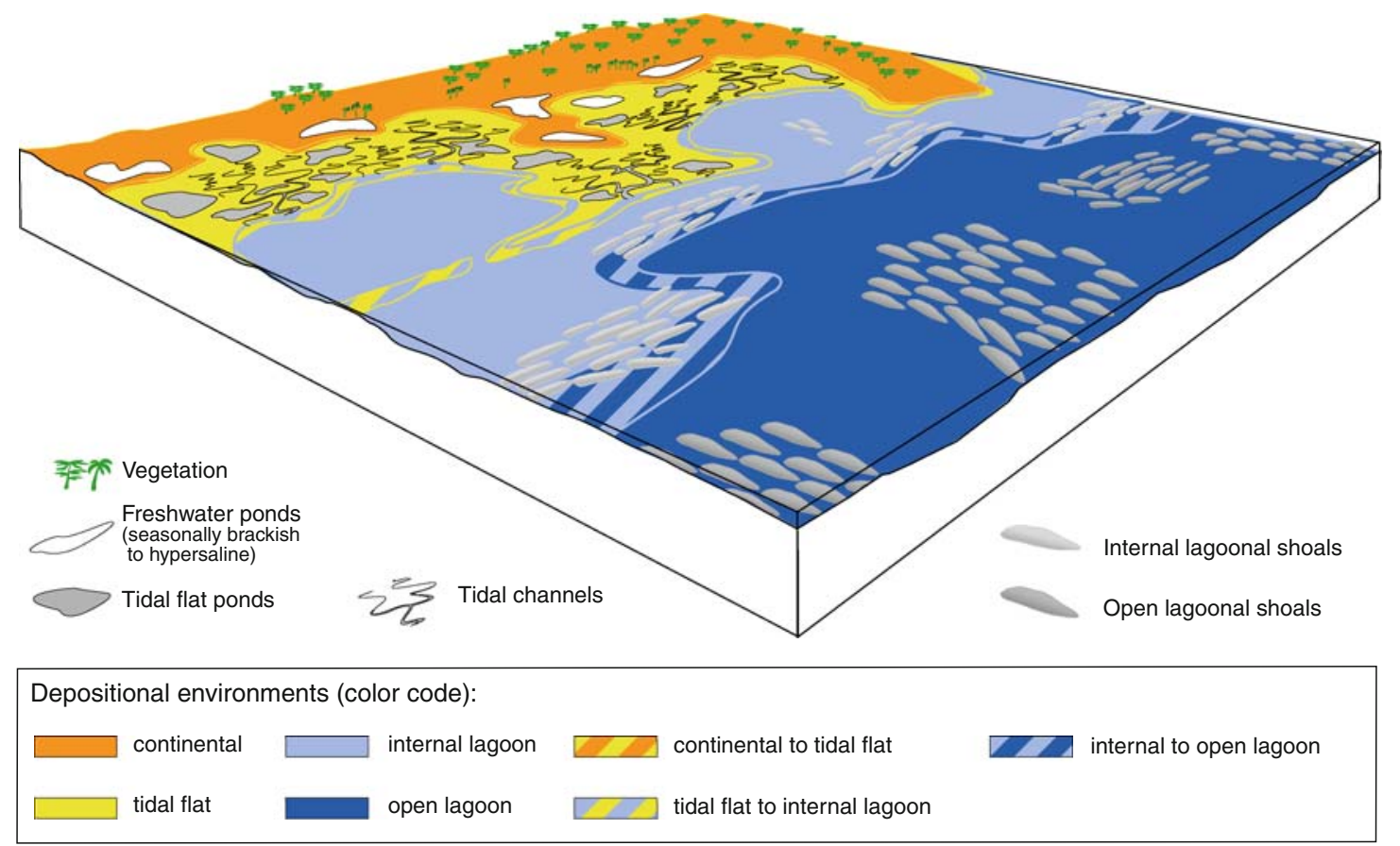

Fig. 5 Block diagram showing the spatial relations between the different depositional environments of the Jura platform (hypothetical, not to scale)

The St. Claude section represents a sedimentary succession of which most parts can be interpreted in terms of sequence stratigraphy (allocycles). The Lavans section, however, is an example where autocyclic deposits are common and a sequence-stratigraphic interpretation is possible only in certain intervals.

\section{Facies evolution of the St. Claude section}

The Goldberg Formation mainly consists of marls and mudstones interpreted as tidal-flat deposits (with birdseyes, lamination, desiccation cracks, and/or circumgranular cracks; Fig. 7). Charophyte-rich intervals are interpreted as tidal pond deposits (at 0.30 and at $2.10 \mathrm{~m}$ ). The presence of marine fauna (echinoderms, foraminifera) is explained by storm washovers when material from the lagoon was flushed onto the tidal flat, or by deposition in tidal channels. The upper part of the Goldberg Formation was dated by Mojon (2002). It is in the range of the assemblage zones M2-M3.

A rapid change to high-energy deposits at the base of the Pierre Châtel Formation (two beds of ooid- and intraclastrich pack- to grainstones) marks a pronounced increase of water depth and energy (from 2.85 to $3.30 \mathrm{~m}$ ). A succession of partly laminated tidal-flat sediments (containing charophytes and ostracodes) caps the second high-energy bed. They indicate a gradual decrease of accommodation space.
The change to a massive bed consisting of tidal flat to internal-lagoonal sediments then reflects a deepening of the depositional system (at 3.65 to $3.85 \mathrm{~m}$ ). The following muddy, thinly bedded, bioturbated interval has been deposited in a restricted, internal-lagoonal environment (low fauna diversity). It is capped by a massive internallagoonal bed. A succession of thinly bedded, ooid-rich wacke- to packstones has been deposited in a restricted internal-lagoonal environment (from 4.00 to $4.50 \mathrm{~m}$ ). Bioturbation at the top of this thinly bedded succession points to condensation and may be related to a slight deepening of the depositional system (at $4.50 \mathrm{~m}$; Fig. 8). Circumgranular cracks at the top of a massive bed are interpreted as signs of emersion of a tidal flat or a restricted, internal-lagoonal environment due to loss of accommodation (at $4.75 \mathrm{~m}$ ).

The following beds have been deposited in an internallagoonal setting (from 4.75 to $5.55 \mathrm{~m}$ ). A slight opening of the depositional system is displayed by a succession of internal- to open-lagoonal deposits (from 5.55 to $6.70 \mathrm{~m}$ ). A nodular interval at the base of the following thick bed consists of internal-lagoonal deposits, suggesting a slight restriction of the system, although the grainstone texture implies an energy increase (at $6.75 \mathrm{~m}$ ). Within this thick bed, a gradual opening of the depositional system is indicated by the deposition of internal- to open-lagoonal sediments, and a deepening is implied by a gradual change from grainstone to wackestone/floatstone. The strongly 
Fig. 6 Legend for the studied sections

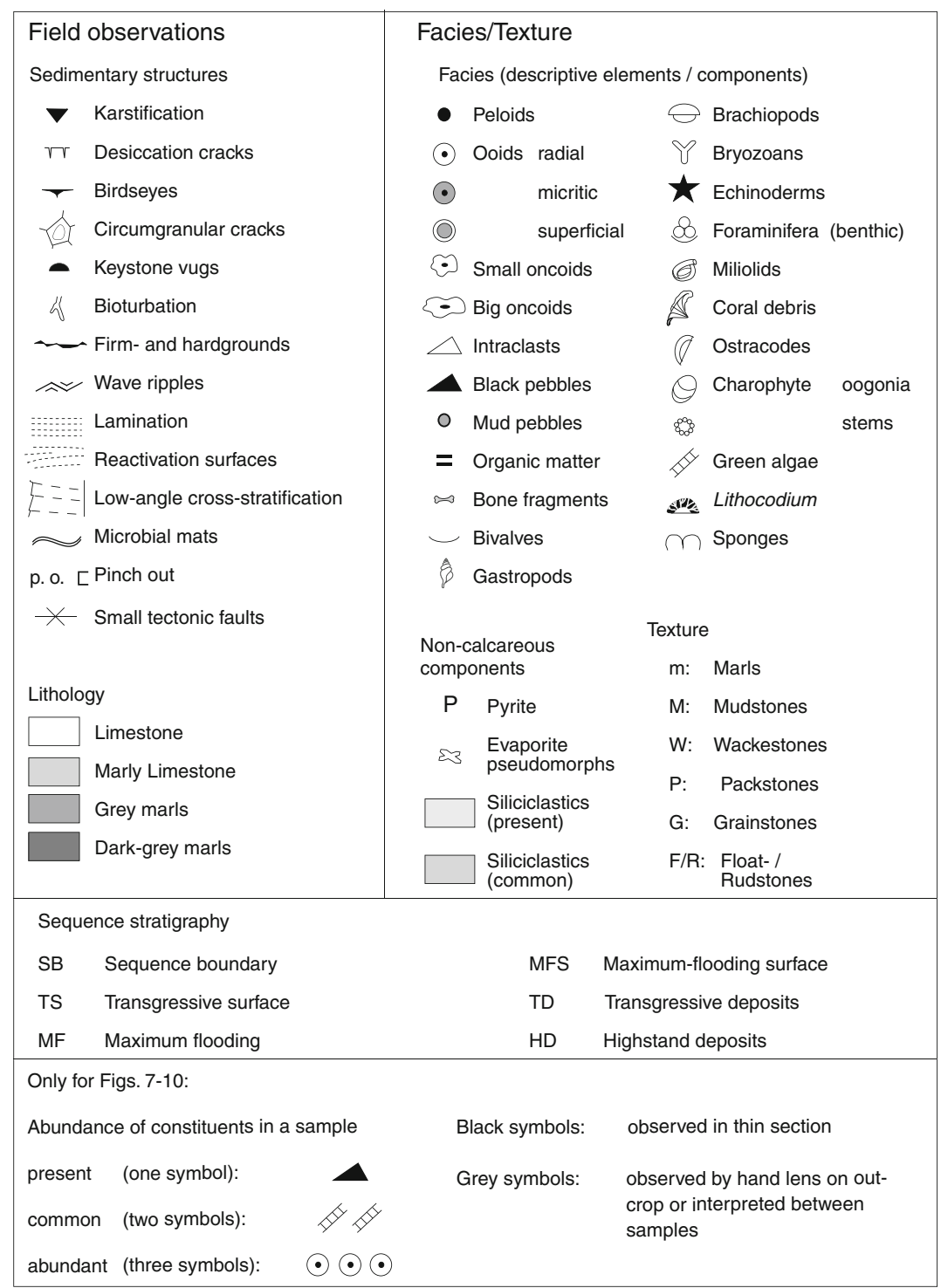

bioturbated floatstone at the top of this bed is interpreted as condensation interval in an open-lagoonal environment (at $7.80 \mathrm{~m})$.

The top of the section is characterized by a massive bed, the facies of which indicates a further opening of the depositional system.

\section{Sequence-stratigraphic interpretation}

of the St. Claude section

Dating by charophyte-ostracode assemblages indicates that the top of the Goldberg Formation contains largescale sequence boundaries Be3 and Be4 (Hardenbol et al. 1998). They are tentatively placed where facies indicate minimum accommodation potential (Fig. 7). Much of the geologic time is probably contained in the packstone bed with reworked clasts (at $2.15 \mathrm{~m}$ ), at the top of the bed showing lateral pinchout and abundant reworked clasts (at $2.40 \mathrm{~m}$ ), and at the very top of the Goldberg Formation (at $2.85 \mathrm{~m})$.

At least three elementary sequences form small-scale sequence 11 (the small-scale sequences are numbered as in Fig. 4). With the help of lateral correlation it is supposed that the first elementary sequence is missing due to nondeposition and/or erosion during the transgression (cf. Fig. 11). The base of the first, ooid-rich, high-energy bed marks the transgression of the Pierre Châtel Formation over the Goldberg Formation. This first bed and the lower part of the second high-energy bed represent the transgressive deposits of small-scale sequence 11. Each of these beds shows a shallowing-up trend culminating in emersion (birdseyes and desiccation cracks), which is interpreted as 
Fig. 7 St. Claude section (part I). For legend of symbols see Fig. 6

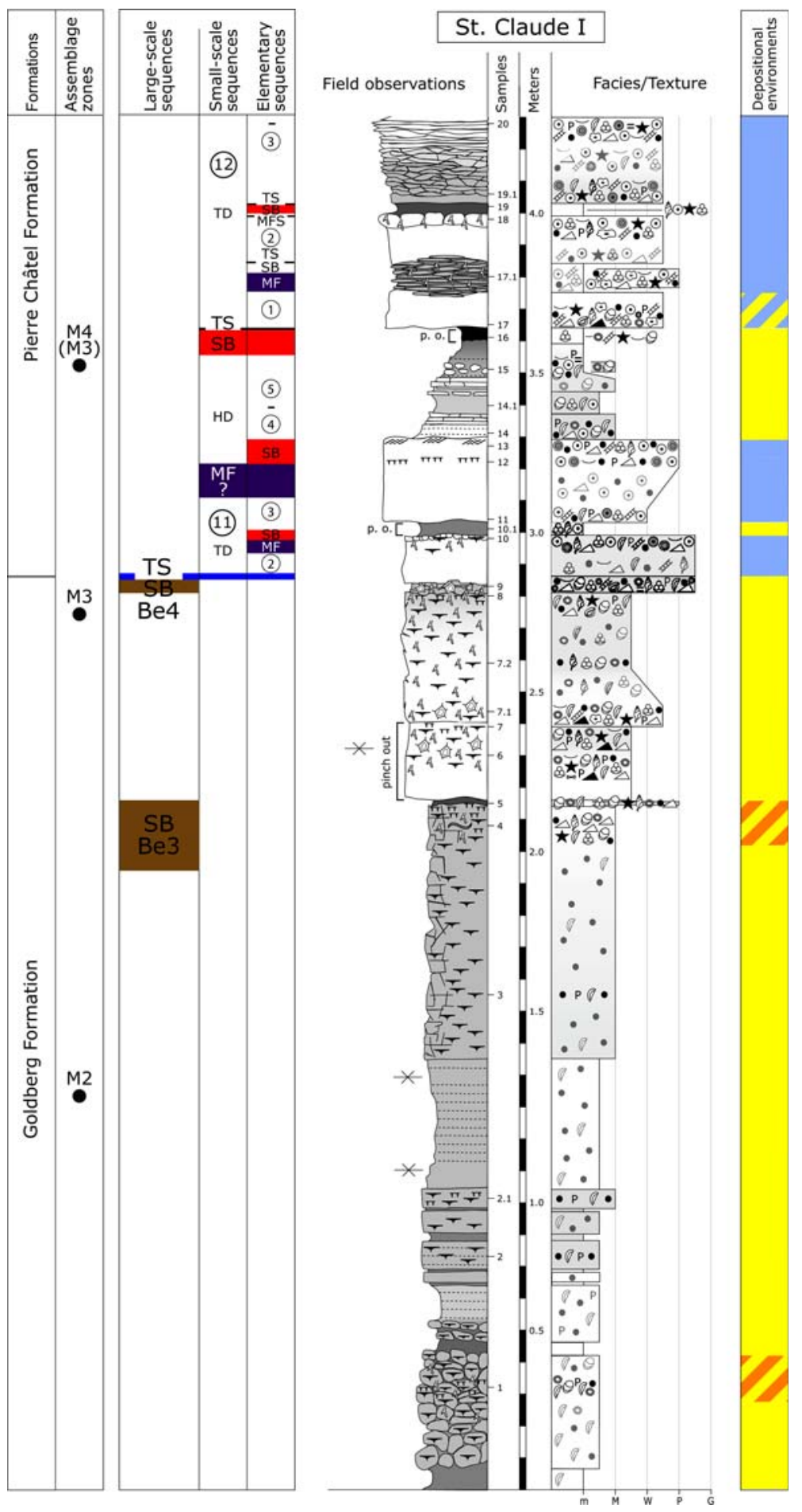

sequence boundary. Accordingly, each bed represents an elementary sequence (the numbering of these elementary sequences anticipates the correlation of Fig. 11). The maximum flooding of small-scale sequence 11 probably lies within elementary sequence 3 , which is the thickest one within this small-scale sequence and thus suggests highest accommodation gain. The succession of tidal-flat deposits terminates this small-scale sequence. The interpretation of elementary sequences in the highstand deposits of this small-scale sequence is not straightforward because diagnostic facies changes are lacking. However, based on lateral correlation, it is supposed that this interval comprehends two elementary sequences (4 and 5; Fig. 11). Lateral correlation also suggests that the 
Fig. 8 St. Claude section (part II)

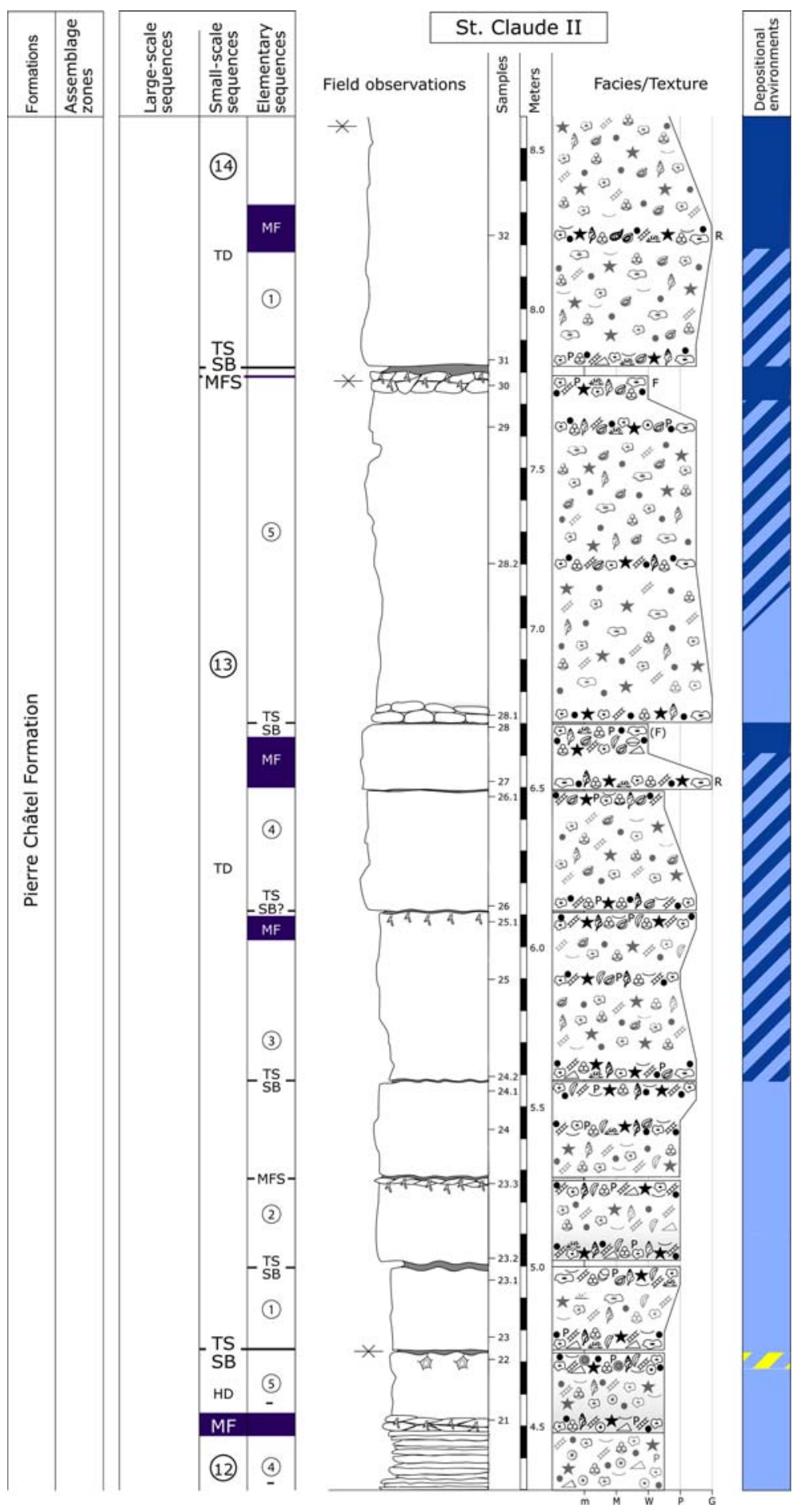

first elementary sequence of small-scale sequence 11 has not been deposited because of a low accommodation space (morphological high), or that it has been eroded during the initial flooding of the platform at the location of the St. Claude section. Also in other sections the first elementary sequence of small-scale sequence 11 is missing (Fig 11).
The top of the tidal-flat succession is interpreted as sequence boundary of small-scale sequence 12 (at $3.65 \mathrm{~m}$ ). The transgressive surface is well defined by reworking and the rapid change from tidal flat to internal-lagoonal deposits at the base of the first massive bed. Each of the following two massive beds is assumed to represent an elementary sequence (1 and 2 ). Their maximum-flooding 
Fig. 9 Lavans section (part I). For legend of symbols refer to Fig. 6

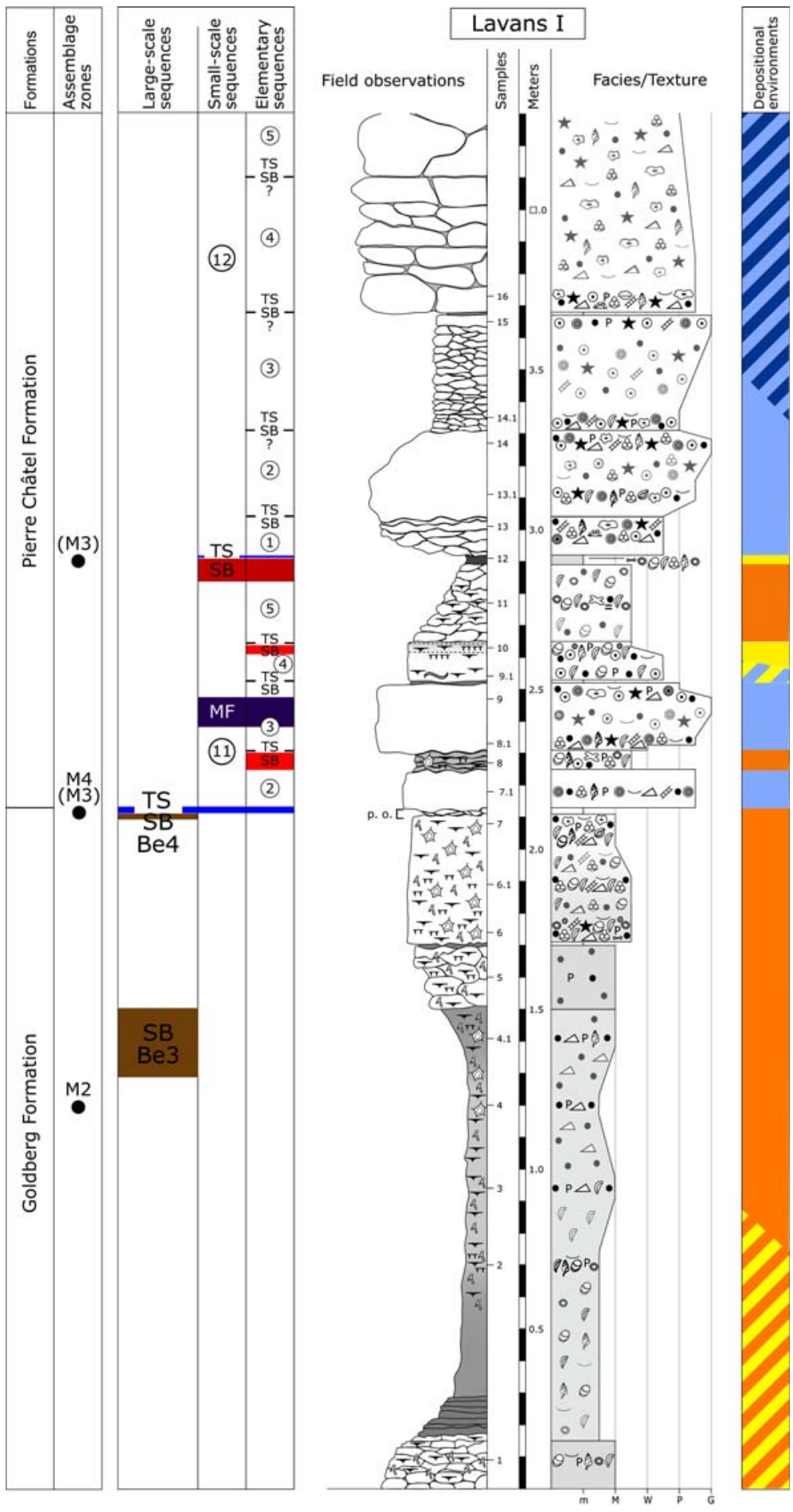

intervals are implied by strong bioturbation. The thinly bedded interval above is thought to contain the third and the fourth elementary sequences. There is no facies change that marks the boundary between these two elementary sequences, but their presence is implied through lateral correlation (Fig. 11). The nodular, strongly bioturbated interval at the top of this thinly bedded succession is considered as maximum flooding of small-scale sequence
12. The highstand deposits are represented by the following massive bed (fifth elementary sequence).

The sequence boundary of small-scale sequence 13 is indicated by an irregular surface above a horizon with circumgranular cracks (at $4.75 \mathrm{~m}$ ). The bed succession is characterized by a general thickening-up trend, which reflects a gain of accommodation during rising relative sea level (transgressive deposits). The identification of 
Fig. 10 Lavans section (part II)

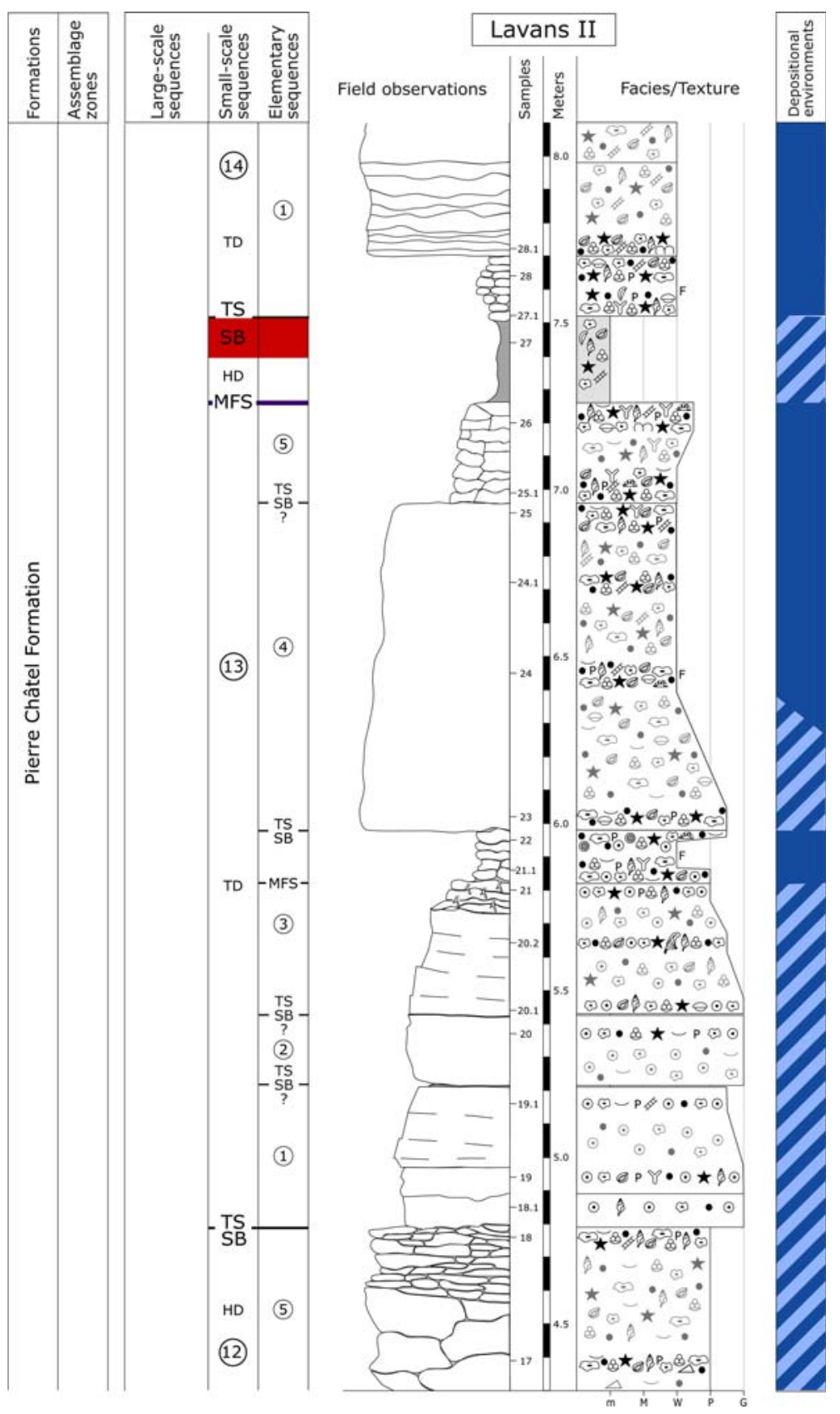

elementary sequences is uncertain in this part of the section. Hence, the sequence-stratigraphic interpretation on the elementary sequence scale is based mainly on lateral correlation (Fig. 11). The discontinuity at the top of the thick massive bed (nodular, bioturbated floatstone at $7.75 \mathrm{~m}$ ) is considered as maximum-flooding surface of small-scale sequence 13 . The highstand deposits of this small-scale sequence are strongly reduced and represented by the marl interval above the maximum-flooding surface.

The sequence boundary and the transgressive surface of small-scale sequence 14 are situated at the base of the following massive bed. The following sedimentary succession displays a continued deepening of the depositional environment.

\section{Facies evolution of the Lavans section}

The top of the Goldberg Formation in the Lavans section consists of tidal-flat deposits (Fig. 9). Storm washovers or extreme tides deposited some foraminifers, dasyclad algae, and echinoderms on these tidal flats. The top of the Goldberg Formation has been dated with charophyteostracode assemblages by Mojon (2002). It belongs to the 

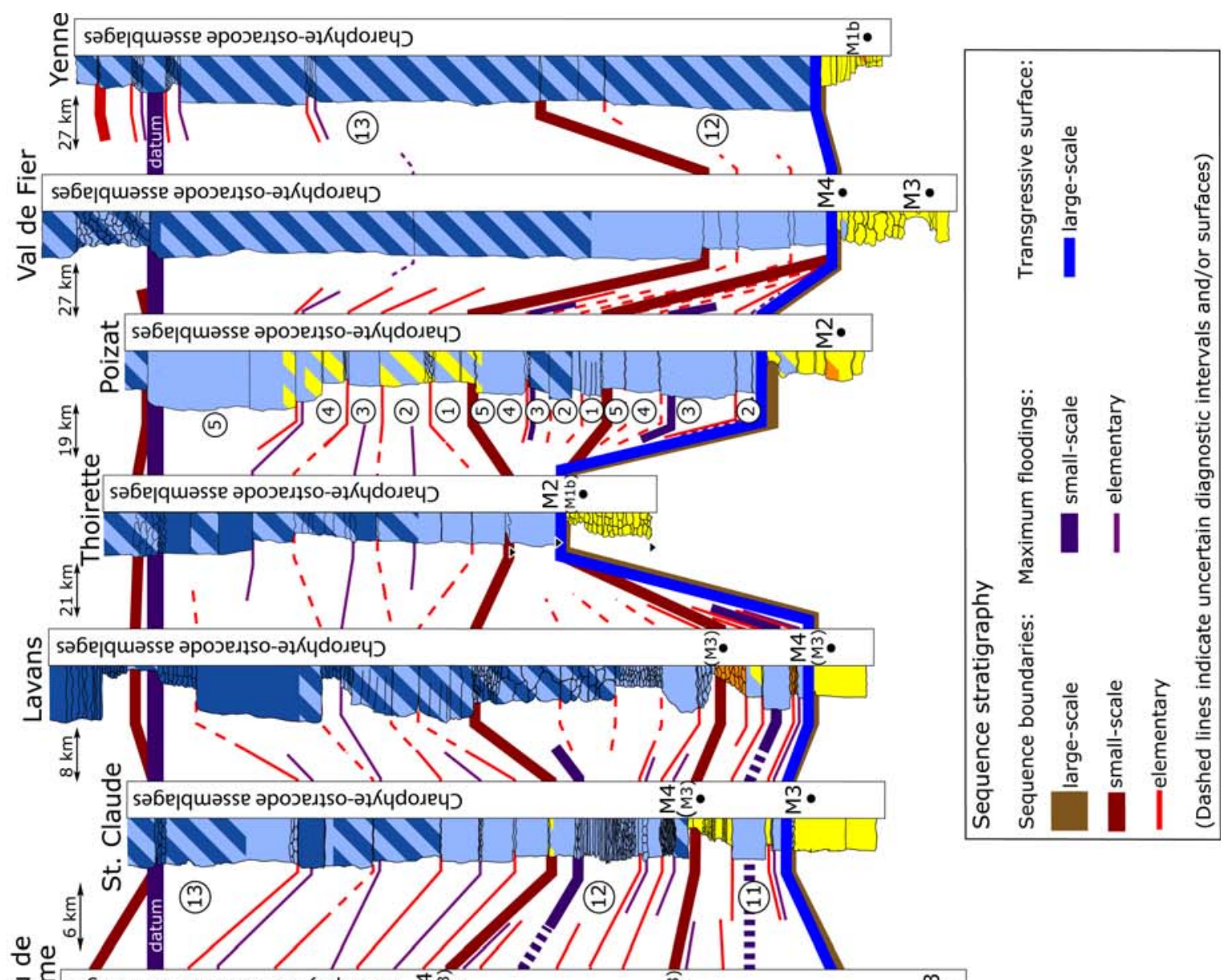

ํํำ
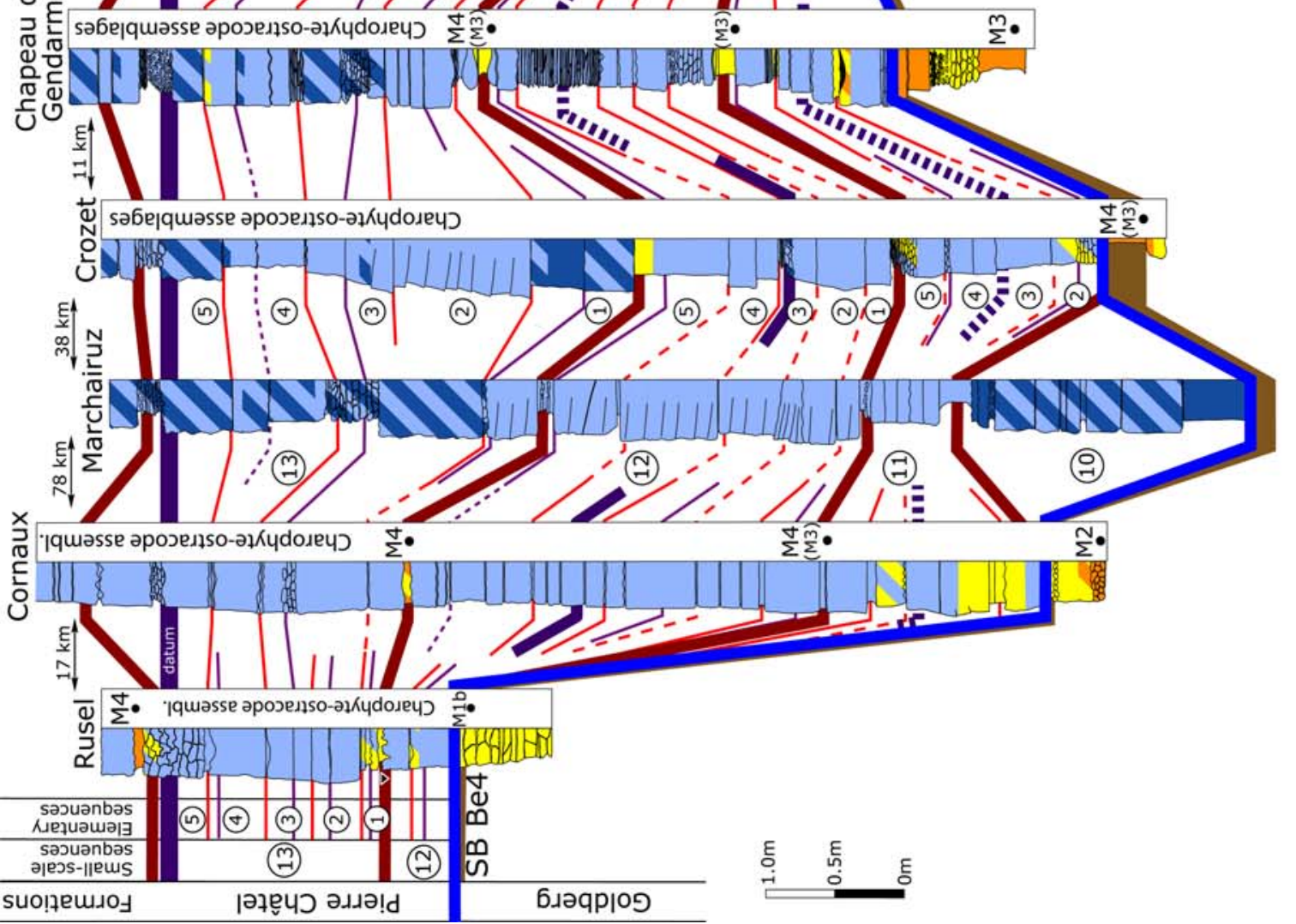
Fig. 11 High-resolution best-fit correlation of the four small-scale sequences 10-13 and their elementary sequences of all studied sections from the Jura platform (Tresch 2007). The sections are represented by their weathering profiles. The depositional environments are indicated by the color code (refer to Fig. 5)

biozone M4 (with reworked species of biozone M3 indicated in brackets).

The base of the Pierre Châtel Formation is characterized by two massive, ooid-rich pack- to grainstone beds (up to $2.50 \mathrm{~m}$ in the graphical $\log$ ). They have been deposited in restricted, internal-lagoonal environments during an increasing accommodation space. The base of the first bed marks the initial flooding of the Jura platform at Lavans and, hence, the boundary between the Goldberg and the Pierre Châtel Formation (Fig. 9). Between these ooid-rich beds, the nodular mud- to packstone interval represents a period of emersion. The following bed is composed of tidal-flat sediments with birdseyes and desiccation cracks. It is overlain by a nodular mud- to wackestone interpreted as supratidal sediments (charophyte stems and gyrogonites), which is capped by a marl level with abundant charophytes. The stratigraphically following beds are composed of internal-lagoonal deposits up to about $3.30 \mathrm{~m}$ where a subtle facies change to a more open-lagoonal composition is indicated. The following interval is characterized by a succession of nodular pack- to grainstones (internal- to open-lagoonal zone). They are capped by an interval of high-energy, internal- to open-lagoonal sediments (pack- to grainstones) with low-angle cross-bedding interpreted as shoal bodies (from 4.80 to $5.85 \mathrm{~m}$ ). The top of this interval is bioturbated, indicating a loss of energy and possibly a deepening. The following oncoid-rich floatstone interval reflects a slight opening of the depositional system. A change to high-energy, internal- to openlagoonal deposits at the base of a thick bed (at $6.00 \mathrm{~m}$ ) points to a decrease of accommodation space. The transition to an open-lagoonal environment within this thick bed is then interpreted as a gradual deepening and opening of the depositional system. The overlying marl interval is composed of internal- to open-lagoonal sediments, which have been deposited during a loss of accommodation space (from 7.25 to $7.50 \mathrm{~m}$ ). A slight deepening of the depositional system is marked by a change to a nodular oncoid-rich floatstone interval (from 7.50 to $7.70 \mathrm{~m}$ ). The following oncoid-rich packstone is attributed to an openlagoonal environment.

\section{Sequence-stratigraphic interpretation of the Lavans section}

Charophyte-ostracode assemblage M4 gives evidence that the top of the Goldberg Formation corresponds to sequence boundary Be4 (Hardenbol et al. 1998).
Based on the correlation with other sections (Fig. 11), it is assumed that the first elementary sequence of small-scale sequence 11 is missing. A rise in relative sea level caused the deposition of the two massive ooid-rich beds. Each of them is interpreted as an elementary sequence (2 and 3). Based on lateral correlation, the maximum flooding of this small-scale sequence lies in the second ooid-rich pack- to grainstone bed. The next pulse of relative sea-level change led to the deposition of tidal flat to emersive deposits represented by the following bed (fourth elementary sequence). Also the fifth elementary sequence consists of tidal flat and continental deposits, indicating that the available accommodation space was constantly filled up.

The sequence boundary of small-scale sequence 12 is set at the top of the emersive interval (at $2.9 \mathrm{~m}$ ). A rise of relative sea level caused the deposition of internal-lagoonal deposits (nodular bed). This bed probably represents the first elementary sequence of this small-scale sequence. The sequence-stratigraphic interpretation of the following bed succession is not straightforward because characteristic facies changes are lacking. It is assumed that this smallscale sequence comprehends at least five elementary sequences. This assumption is based on lateral correlations (Fig. 11).

The base of the high-energy shoal succession marks the transgressive surface of small-scale sequence 13 (at $4.8 \mathrm{~m}$ ). The detailed sequence-stratigraphic interpretation of these deposits is not evident because they have probably been controlled by autocyclic processes. Considering lateral correlations, they contain up to three elementary sequences (Fig. 11). The floatstone interval at the top of the shoal succession is assumed to reflect condensation during rapidly rising relative sea level. The facies change towards internal- to open-lagoonal deposits at the base of the massive, thick bed is considered as a slight decrease of relative sea level. It is interpreted as sequence boundary of the fourth elementary sequence. The discontinuity at the base of the thick marl interval is considered as the maximum-flooding surface of small-scale sequence 13 .

A decrease of relative sea level then caused the influx of clays and deposition of the marl interval (internal- to openlagoonal deposits). The sequence boundary of small-scale sequence 14 is placed at its top, and the overlying transgressive surface is suggested by the change to clearly openlagoonal facies.

Correlation of small-scale and elementary sequences

The correlation of diagnostic intervals and/or surfaces of the 11 sections on the Jura platform is displayed in Fig. 11. As a working hypothesis, the maximum flooding of small-scale sequence 13, well expressed in all studied sections, has been used as datum for the lateral correlation. The sequence 

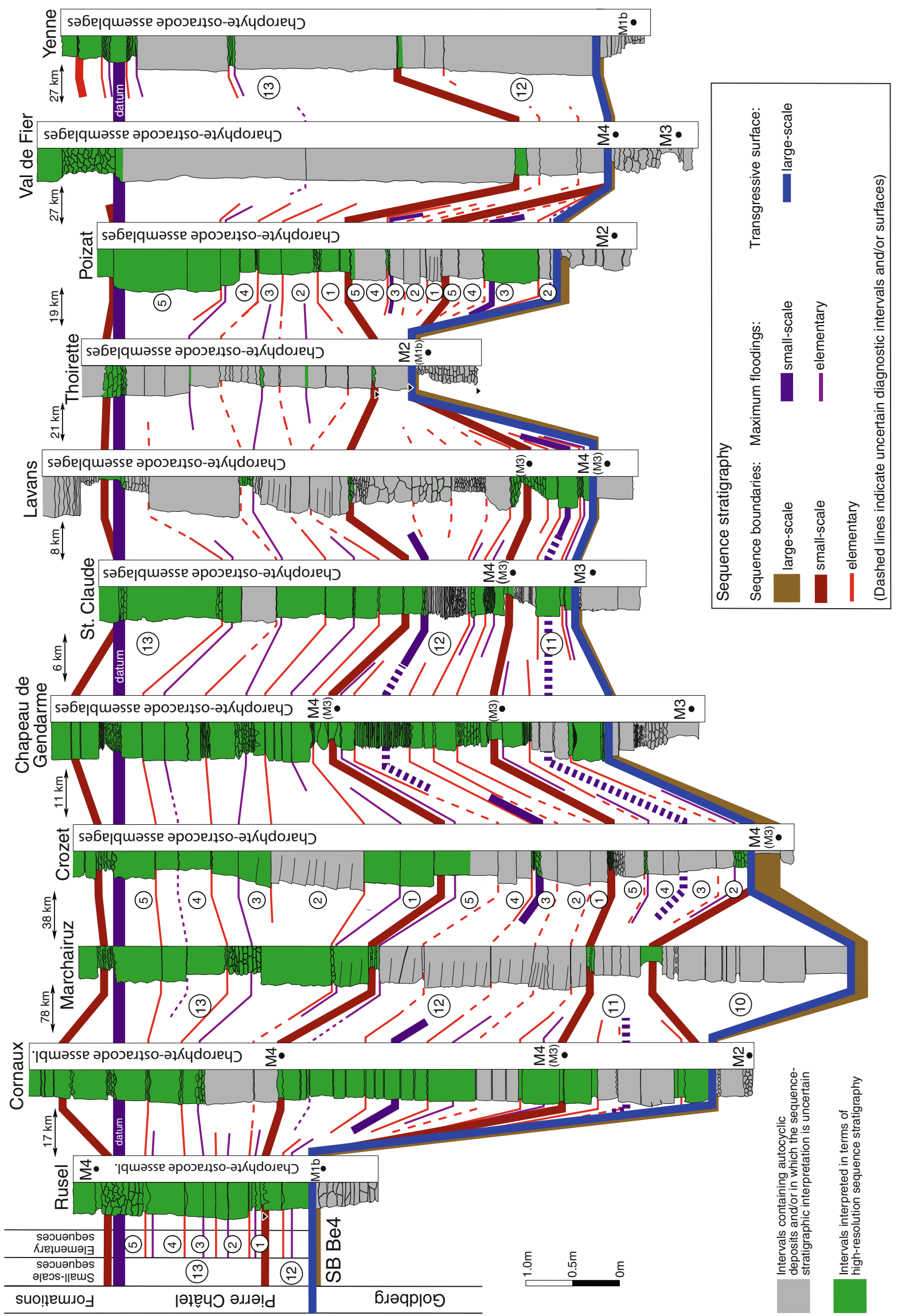
4 Fig. 12 Best-fit correlation of the four small-scale sequences 10-13 and their elementary sequences. Intervals containing autocyclic deposits and/or of which the sequence-stratigraphic interpretation is uncertain are shown in gray

boundaries of the small-scale sequences are all well developed and can be traced from section to section. The interpretation of the maximum floodings in small-scale sequences 10-12, however, is more delicate and can be determined and correlated with certainty between only some sections. Nevertheless, the best-fit correlation of the small-scale sequences can be used as a framework for the correlation of elementary sequences. The sequence boundary between small-scale sequences 12 and 13 is especially well expressed by the relatively most proximal facies in each sedimentary succession (e.g., karst surfaces in the Rusel and Thoirette sections, tidal-flat deposits in the Crozet and Chapeau de Gendarme sections). This points to a pronounced relative sea-level fall affecting the entire study area (medium-scale sequence boundary; Tresch 2007) (Fig. 4).

The interpretation of elementary sequences on the Jura platform is generally not straightforward (Fig. 12). In some sections, they can be interpreted without any doubt (e.g., Rusel section). In most sections, however, the interpretation of elementary sequences is not or only partly possible because autocyclic processes probably dominated the deposition of the sediments. Yet, autocyclic deposits such as tidal channel fills or shoal bodies are commonly of limited lateral extension (Ginsburg 1971; Pratt and James 1986; Strasser 1991). In the investigated sections, some shoal bodies have been identified (e.g., sections of Marchairuz, Crozet, and Lavans in Figs. 10, 11). Although the facies succession within these autocyclic intervals cannot be interpreted in terms of sequence stratigraphy, they can at least be delimited at their base and top by sequence-stratigraphic correlations (Fig. 12).

The sections of Val de Fier and Yenne are composed of relatively thick beds of internal- to open-lagoonal deposits, in which no characteristic facies changes occur (Fig. 11). In these sections, the sea floor never reached intertidal or supratidal conditions, so that the expression of diagnostic intervals or surfaces is weak or absent (subtidal cycles sensu Osleger 1991). The amplitude of the sea-level

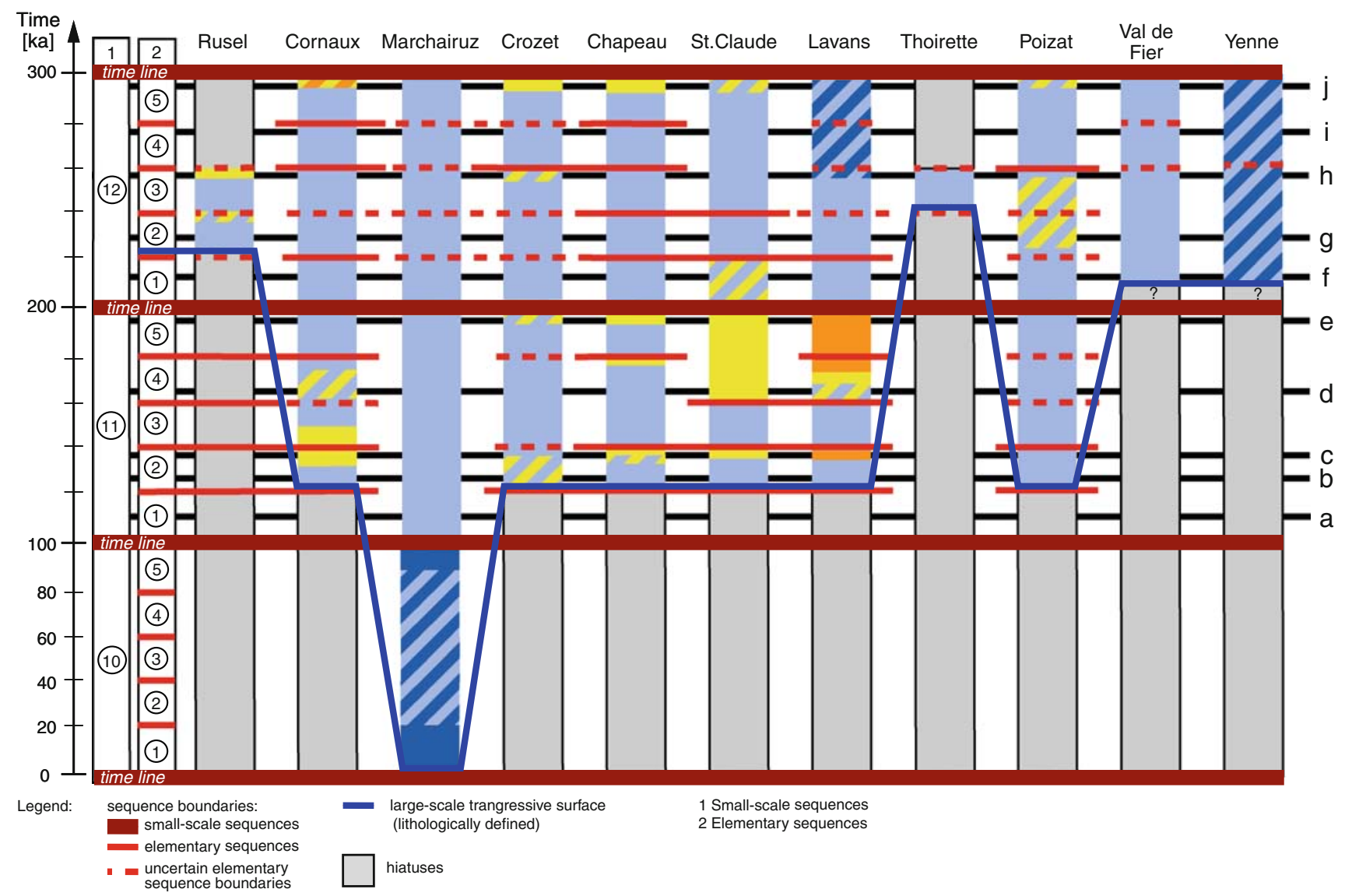

Fig. 13 Time-space diagram illustrating the depositional environments indicated by the corresponding color code (Fig. 5) of smallscale sequences 10-12 and their elementary sequences of all investigated sections of the Jura platform. The sequence boundaries of the small-scale and elementary sequences are considered as time lines delimiting 100-ka and 20-ka orbital cycles. For time lines a to $\mathrm{j}$ refer to Fig. 15 

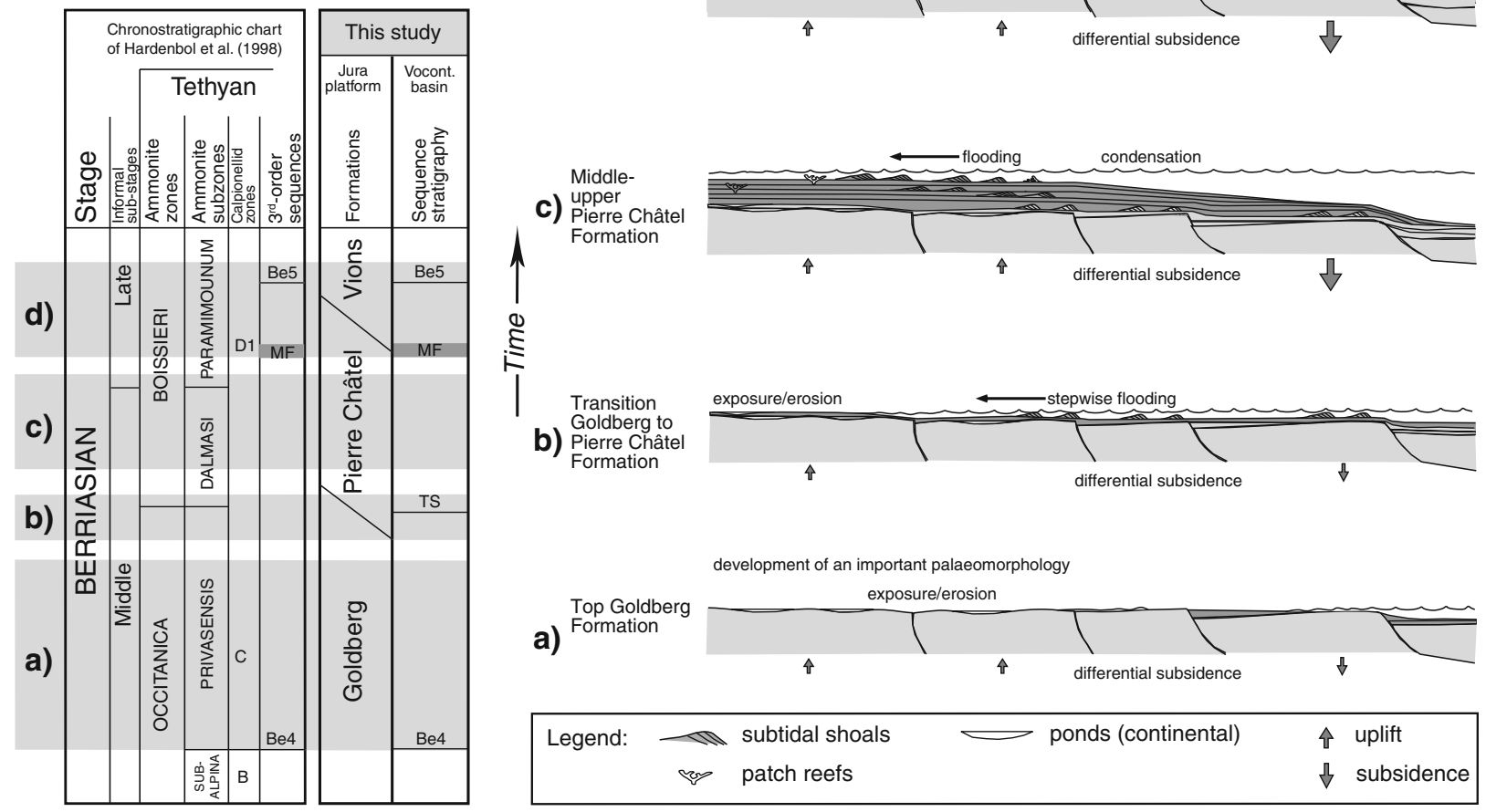

Fig. 14 Long-term evolution of the Jura platform between the largescale sequence boundaries $\mathrm{Be} 4$ and $\mathrm{Be} 5$. Approximate timing (left side) and illustration (right side) of a long-term lowstand interval,

changes induced by the 20-ka precession cycle was too low to create facies changes in deep water, and only the more important sea-level fluctuations linked to the 100-ka eccentricity cycle were recorded. Consequently, in these two sections, only the sequence boundaries of the smallscale sequences can be correlated (Fig. 11).

A time-space diagram has been constructed in order to better illustrate the lateral and vertical evolution of the depositional environments during the early stages of the Middle Berriasian transgression. This diagram (Fig. 13) illustrates the high-resolution correlation of the small-scale sequences $10-12$ and their elementary sequences of the sections as displayed in Fig. 11. According to the cyclostratigraphic interpretation, each small-scale sequence represents an equal time increment of $100 \mathrm{ka}$, and each elementary sequence a time increment of $20 \mathrm{ka}$. The sequence boundaries are assumed to represent time lines, which delimit the depositional sequences. The depositional environments between the time lines have been interpolated (compare with Fig. 11). This diagram, however, does neither account for different sedimentation rates, which are strongly facies-dependent, nor for non-deposition and/or erosion between two time lines. b initial transgression, $\mathbf{c}$ long-term transgressive interval, $\mathbf{d}$ long-term

As illustrated in the time-space diagram, the time lines (sequence boundaries) cut through the large-scale, lithologically determined transgressive surface defining the base of the Pierre Châtel Formation. This implies that the Middle Berriasian transgression was strongly diachronous on the Jura platform. According to the sequence-stratigraphic bestfit correlation and the cyclostratigraphic interpretation of this study, the initial flooding of the Jura platform had a time lag of up to $220 \mathrm{ka}$ between the Marchairuz and the Rusel sections (Fig. 13). In six of the 11 sections, however, the initial transgression is recorded at the base of small-scale sequence 11 in the second elementary sequence. Therefore, over a distance of several tens of kilometers, the initial transgression occurred in the same 20-ka cycle.

Long-term evolution of the Jura platform during the Middle to Late Berriasian

The cross-sections shown in Fig. 14 illustrate the evolution of the Jura platform in four time intervals. They give an overview of the long-term interactions between tectonics (subsidence or uplift) and eustasy between the large-scale sequence-boundaries Be4 and Be5. highstand interval. The illustrations are not to scale 
Lowstand deposits (Fig. 14a)

Lowstand deposits on the Jura platform are strongly reduced and/or absent due to erosion and non-deposition during the Early to Middle Berriasian. Continental to intertidal deposits characterize the top of the Goldberg Formation. The dating by charophyte-ostracode assemblages (Mojon 2002) reveals that the top of the Goldberg Formation represents different time intervals at different localities on the platform (M1b to M4; Fig. 11). This is probably due to the development of an important platform morphology following recurrent emersions during the Early to Middle Berriasian, and to differential subsidence (block rotation combined with uplift; Détraz and Steinhauser 1988; Strasser 1988; Détraz and Mojon 1989; Pasquier 1995). These factors controlled the evolution of the complex pattern of morphological highs and depressions on the platform. A reef complex and shallow lagoons formed during the Late Tithonian to early Middle Berriasian on parts of the southern Jura platform, but emerged and were brecciated during sea-level lowstand in Early to early Middle Berriasian times (reef of Echaillon; Détraz and Steinhauser 1988; Détraz and Mojon 1989). The growth of the reef complex during the Late Tithonian to early Middle Berriasian formed a relatively steep slope at the transition from the southern Jura platform to the western Helvetic shelf (Détraz and Steinhauser 1988).

\section{Initial transgression (Fig. 14b)}

High-resolution sequence- and cyclostratigraphic investigations reveal that the transgression flooded the Jura platform diachronously (Waehry 1989; Pasquier 1995; Hillgärtner 1999; Strasser et al. 2004; Tresch 2007; Fig. 13). The timing of the initial flooding at a given locality on the platform depends on its pre-existing morphology, which plays an important role by locally modifying accommodation and facies distribution.

\section{Transgressive deposits (Fig. 14c)}

The transgressive deposits of the Jura platform display a general thickening-up trend, reflecting an important gain of accommodation space. The potential for carbonate production was elevated due to a combination of warm waters in subtropical latitudes, low detrital input, and enhanced water circulation on the platform favoring oligotrophic conditions. The growth potential of the Jura platform was high and patch reefs grew in shallow lagoons (Pasquier 1995; Hillgärtner 1999). Bioclastic shoal fields protected the shallow lagoons from open-marine waters on the southern Jura platform (Détraz and Mojon 1989). The interaction of rising sea level in combination with differential subsidence created a complex pattern of lateral and vertical facies successions. Subsidence rates generally increased from proximal to distal (from the Jura platform to the Helvetic shelf) due to extensional tectonics on the northern margin of the Tethys (e.g., Funk 1985; Arnaud 1988; Wildi et al. 1989; Loup 1992; Pasquier 1995). Accelerated differential subsidence and rising sea level initiated the change from a flat-topped platform during the Early to Middle Berriasian to a distally steepened ramp during the late Middle to early Late Berriasian (Dalmasi to Paramimounum ammonite subzones; Détraz and Steinhauser 1988; Hillgärtner 1999).

\section{Maximum flooding and highstand deposits (Fig. 14d)}

After the initial flooding of the flat-topped Jura platform and the start-up phase in platform growth during the largescale transgression, high carbonate production progressively outpaced accommodation (shallowing-up trend) and forced the platform to prograde (Hillgärtner 1999). Except for some sections (Pasquier 1995; Pasquier and Strasser 1997), the large-scale maximum-flooding interval is not recorded on the Jura platform. It is assumed that a combination of sea-level fall, tectonic uplift, and/or reduced subsidence rates as well as the climate change to more humid conditions led to karstification, which marks the transition from the Pierre Châtel to the Vions Formation in several locations (Pasquier 1995; Pasquier and Strasser 1997; Hillgärtner 1999; Strasser et al. 2004; Fig. 4).

Short-term evolution of the Middle Berriasian Jura platform

With the help of the time-space diagram (Fig. 13), the complex pattern of depositional environments can be investigated. Small-scale sequences 11 and 12 are used to illustrate the evolution of the initial transgression on the Jura platform. Five time-slices for each of these two smallscale sequences have been chosen in order to reconstruct hypothetical palaeogeographic maps (Fig. 15a-j). No palinspastic reconstruction has been made, i.e., the distances between the sections and their relative positions are not corrected. The proximal-distal distribution of the sections relative to the palaeocoast, however, is not affected and can be considered as representative. The depositional zones between the investigated sections are interpolated according to the facies and sequence-stratigraphic interpretations of Tresch (2007) and data from the literature (e.g., Strasser 1987; Détraz and Mojon 1989; Waehry 1989).

The Jura platform and the northern parts of the Helvetic shelf have been flooded approximately from southwest to northeast (e.g., Détraz and Steinhauser 1988; Waehry 1989; Pasquier 1995). The transgression encroached 


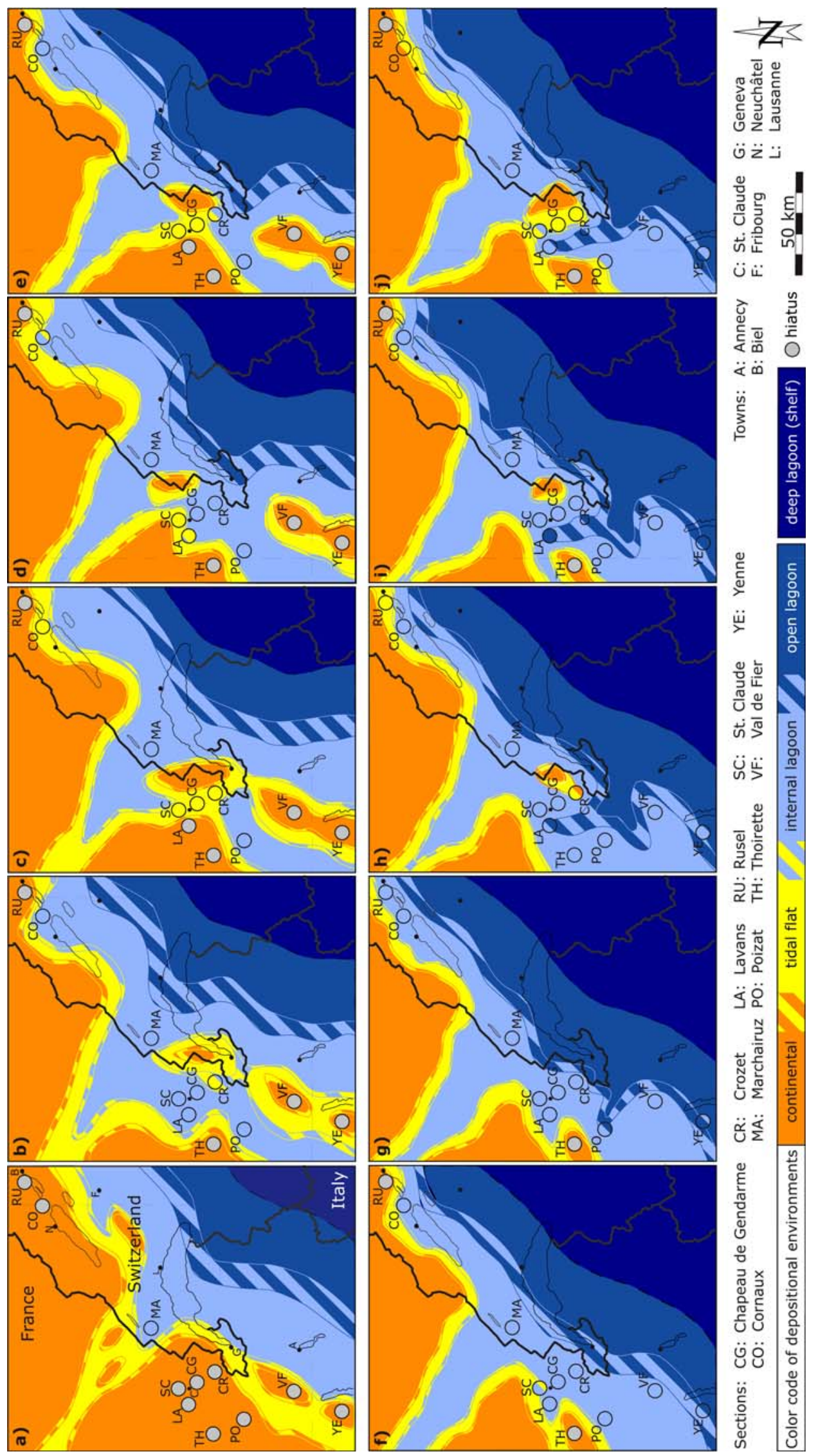


Fig. 15 Ten palaeogeographic maps $(\mathbf{a}-\mathbf{j})$ of small-scale sequences 11 and 12. The time slices represented on the palaeogeographic maps are indicated on the time-space diagram in Fig. 13. The interpolations of depositional environments between the sections are hypothetical. The palaeogeographic maps are shown without palinspastic reconstructions

stepwise onto the emerged platform at the transition of the Goldberg Formation to the Pierre Châtel Formation (Pasquier 1995; Strasser et al. 2004; Tresch 2007). The preexisting platform morphology and the tectonic setting (uplift or subsidence) were the main factors controlling the time of the initial flooding at a given location. According to the sequence-stratigraphic interpretation, emersion prevailed on the southwestern Jura platform (Yenne and Val de Fier sections) about $100 \mathrm{ka}$ longer than in more northern locations (Fig. 13). This interpretation may be explained by emerged morphological highs (islands), which were separated from the mainland in the northwest by a shallowmarine lagoon in the area of the Poizat section (Fig. 15be). The initial transgression in these elevated areas is marked by an abrupt facies change from supratidal to lagoonal sediments without any transitional environments such as tidal flats. This points to a relatively distal position on the platform and/or to rapid tectonic subsidence.

A similar interpretation has been made for the Thoirette section. However, at this location, it is not clear whether the facies evolution indicates a distal or a proximal position on the platform. It is supposed that this section was first situated on the emerged mainland (Fig. 15a-g), then in an internal-lagoonal environment (initial transgression; Fig. 15h) and later on an island (Fig. 15i-j). An emerged morphological high (island) is also postulated east of the Crozet, Chapeau de Gendarme, and St. Claude sections (Fig. 15b-e). During the transgression in small-scale sequence 12, however, this morphological high was flooded (Fig. 15f-g). An island in this area probably reappears during low relative sea level (Fig. 15h-j).

The sequence-stratigraphic correlation shows that smallscale sequence 10 of the Marchairuz section is composed of internal- to open-lagoonal deposits (Figs. 11, 13). This implies that, in the area of the Marchairuz section, the Jura platform was flooded earlier than at the locations of the other sections. This suggests that the section of Marchairuz was located in a morphological depression. Facies analysis, the thickness of the formations, and the distribution of detrital quartz in the area of the Marchairuz section have been related to a shallow basin (Steinhauser and Charollais 1971; Persoz and Remane 1976; Strasser 1987). Based on micropalaeontological arguments, Mojon (2002) postulated a marine connection in this region between the Jura platform and the Paris basin (Central Jura graben). Tectonic movements along Variscan structures in the basement probably controlled the Mesozoic subsidence pattern of the
Jura platform (Loup 1992) and the evolution of this graben system (Mojon 2002). The present study supports this interpretation because the initial transgression (represented by open-lagoonal deposits) reaches the Marchairuz area already in small-scale sequence 10 (Figs. 11, 13). Accordingly, an elongated shallow basin with a southeast to northwest orientation has been sketched in the area of the Marchairuz section. The existence of a marine connection to the Paris basin during the deposition of smallscale sequences 11 and 12 is highly speculative. However, with increasing relative sea level and during the large-scale maximum flooding (around small-scale sequence 19 in Fig. 4), the Jura platform may have been connected with the Paris basin by a shallow-marine depression.

Increased differential subsidence probably caused the environmental change from internal- to more open-lagoonal conditions in the area of the Poizat section during the deposition of small-scale sequence 12 (Fig. 15g). About 20 ka later, a similar abrupt change from internal- to openlagoonal deposits occurred at the location of the Lavans section (Fig. $15 \mathrm{~g}-\mathrm{h}$ ), which probably also indicates a relative increase of differential subsidence. As a hypothesis, this may be explained by a northward propagation of tectonic activities along a fault zone during the Middle Berriasian (Vuache fault zone; Charollais et al. 1983).

The facies evolution of the Rusel section indicates that it was located at the most proximal position on the platform compared with the other sections (e.g., freshwater interval at the sequence boundary between small-scale sequences 13 and 14; Fig. 11). About $2 \mathrm{~km}$ to the northeast of the Rusel section in direction to the town of Biel (cf. Fig. 1), the Biel section has been investigated in several studies (Mojon and Strasser 1987; Blanc and Mojon 1996; Blanc 1996; Mojon 2002). A breccia interval containing a tilted block with a volume of almost $3 \mathrm{~m}^{3}$ occurs at the base of the Pierre Châtel Formation. Mojon and Strasser (1987) postulated that this block had fallen down from a Middle Berriasian palaeocliff. Blanc and Mojon (1996) and Blanc (1996) related the breccia and the tilted block to collapse deposits, which filled a karst cave during the Middle to Late Berriasian (charophyte-ostracode assemblage M4). These interpretations indicate that the coastline was close to the sections of Rusel and Biel at least during the Middle Berriasian.

\section{Discussion}

On shallow carbonate platforms, the thickness of the depositional sequences reflects, as a first approximation, the changing accommodation space over time. However, sequence thickness as seen in the field and accommodation do not have a linear relationship. This is due to facies- 
dependent differential compaction and because sediment not always fills up the available space (Strasser et al. 1999). Accommodation changes are controlled by the combination of eustatic sea-level changes and tectonic movements. Furthermore, morphology on the platform is created by local accumulation of sediment in shoals, or by the construction of bioherms. The fact that depositional sequences can be correlated over long distances (tens of kilometers) along the Jura platform is a strong argument that processes other than local tectonic activities or local changes in sediment accumulation must have been involved. The hierarchical stacking pattern observed in the studied sections implies that it was mainly the superposition of highfrequency sea-level fluctuations on a longer-term trend that was responsible for the formation of depositional sequences of several orders (large-, medium-, small-scale sequences). Lateral thickness changes within the same sequence are attributed to differential subsidence and facies-dependent differential compaction.

While small-scale sequences can be correlated relatively easily over the whole study area, interpretation and correlation of elementary sequences is more problematic. On this scale of investigation, local factors partly dominated the depositional processes. Different autocyclic models have been proposed to explain the stacking pattern and/or the facies evolution of shallow-marine sedimentary successions (e.g., Ginsburg 1971; Pratt and James 1986; Cloyd et al. 1990; Satterley 1996). Other researchers used statistical methods to proof the randomness of sedimentary successions (e.g., Drummond and Wilkinson 1993a, b; Wilkinson et al. 1996, 1997). These models, however, convince only for laterally discontinuous shallowing-up sequences (Schlager 2005). Accordingly, autocyclic deposits such as tidal channel fills or shoal bodies are of limited lateral extension and, hence, cannot be correlated over long distances. Moreover, autocyclic models do not explain subtidal sequences and/or sequences characterized by vadose diagenetic overprints and/or karstification (e.g., Kendall and Schlager 1981; Osleger 1991; Osleger and Read 1991; Strasser 1991), which have been observed in the investigated sections.

The studied Middle Berriasian deposits of the Jura platform contain intervals, which cannot be interpreted in terms of sequence stratigraphy (Fig. 12). This is explained by autocyclic sedimentation processes and/or due to the absence of threshold effects, which normally would lead to characteristic facies contrasts in the sedimentary record.

Also the position on the platform is an important parameter controlling the sedimentary succession of a section. It can be assumed that in relatively distal positions on a platform rim a transgression leads to a rapid change from island or tidal flat to lagoonal deposits. Such an environmental change is displayed in the sediments of the
Thoirette, Poizat, Val de Fier, and Yenne sections (southwestern platform; Figs. 11, 13, 15). Conversely, the sedimentary succession in proximal platform positions is characterized by repeated facies changes from tidal flat to lagoonal and back to tidal-flat environments because accommodation generally is low (Rusel and Cornaux sections; northwestern platform; Fig. 15). The other sections display combinations between characteristics of typical distal and proximal settings. However, it is assumed that the coastline of the Jura platform was not linear but displayed promontories and bays (Strasser et al. 2004), thus further complicating the palaeogeographic distribution of depositional environments.

At the transition from the Goldberg to the Pierre Châtel Formation, the Jura platform was exposed for an extended period of time (Strasser 1988; Waehry 1989; Strasser 1994; Pasquier 1995; Pasquier and Strasser 1997; Strasser and Hillgärtner 1998; Hillgärtner 1999; Strasser et al. 2004; Tresch 2007). During this exposure, an important morphology developed, which divided the platform into a complex pattern of morphological highs and depressions. Such pre-existing morphology strongly determines the geometry of the coastline and the distribution and migration of depocentres on the platform during the transgression. It also modifies the hydrodynamic conditions (current and/or wave directions and intensity), the pattern of sediment production and deposition, and ecological conditions (e.g., water depth, salinity, turbidity, and nutrient distribution) during the flooding of the platform. This is important for carbonate-dominated shallow-marine platforms, on which the source (carbonate factory) and the distribution of sediments strongly depend on local conditions (Schlager 2005). The rapid flooding of a platform changes the physical and chemical conditions for the biota and, hence, influences the in-situ carbonate production (e.g., Tipper 1997; Wright and Burgess 2005).

Accommodation changes between the sections are related to differential subsidence. The Jura platform was divided into several tectonic compartments with different subsidence rates. Low subsidence and/or uplift were responsible for the exposure of the Jura platform around the large-scale sequence boundary Be4 (Strasser and Hillgärtner 1998; Hillgärtner 1999). The sequencestratigraphic correlation across the Jura platform also suggests that in some sections (e.g., Rusel and Chapeau de Gendarme; Fig. 4) the topmost depositional sequences were truncated by karst surfaces during the formation of sequence boundary Be5. Other sections of the Jura platform show a similar phenomenon (Pasquier 1995; Hillgärtner 1999). A fall of eustatic sea level alone cannot explain such exposure features, and tectonic activity (e.g., block faulting) has to be considered at that time (e.g., Pasquier 1995; Hillgärtner 1999; Strasser et al. 2004). 
In shallow-marine deposits, important parts of the geological record are lost in discontinuity surfaces by nondeposition and/or erosion (Read et al. 1986; Strasser 1994; Hillgärtner 1998, 1999; Strasser et al. 1999; Strasser and Samankassou 2003). Sedimentary successions of such environments thus only represent a fraction of the geological time (e.g., Wright 1994; Immenhauser and Scott 2002; Burgess and Wright 2003; Miall and Miall 2004). Nevertheless, the present study suggests that even if a depositional sequence represents only part of the geologic time, the hierarchical stacking is not affected and can be used in the sequence- and cyclostratigraphic interpretation. Furthermore, by the correlation of elementary and smallscale sequences between different sections, the exact timing and the palaeogeographic location of the hiatuses can be reconstructed.

\section{Conclusion}

The proposed 20-ka framework allows to investigate environmental changes with a very high time resolution. It can be shown that facies change rapidly in time and space in the order of a few thousand years. Depositional environments may migrate over several tens of kilometers within a 20-ka sea-level cycle, strongly depending on the local accommodation space, energy conditions, platform morphology, and/or production and transport rates of the sediments. The superposition of long- and short-term processes has to be considered when interpreting highly dynamic depositional systems. Tectonic processes (uplift or subsidence) may change accommodation space locally and regionally by controlling the long-term evolution of the platform morphology. The short-term evolution of marginal-marine environments is strongly coupled to sea-level changes that are controlled by orbitally induced climate changes (Milankovitch frequency band).

In shallow-marine carbonate systems, autocyclic processes may overrule the high-frequency allocyclic signal. Additionally, the absence of facies changes in deeper-water deposits may complicate the sequence-stratigraphic interpretation of elementary sequences. Nevertheless, the correlation of the small-scale sequences is relatively straightforward, and their boundaries help to constrain autocyclically controlled intervals or intervals with no discernible elementary sequences. The combination of sequence- and cyclostratigraphy has an enormous potential to investigate marginal-marine carbonate systems with high resolution in time and space. It opens the possibility to quantify sedimentological, ecological, and diagenetic processes of the past within time increments of $20 \mathrm{ka}$ or less. Thus, the time resolution approaches that of the Pleistocene and Holocene where the controlling factors are much better known, and comparisons between the Recent and the past become much more realistic.

Acknowledgments This study results from the Ph.D. research of Jonas Tresch at the Department of Geosciences of the University of Fribourg (Switzerland). It has been financed by the University of Fribourg and the Swiss National Science Foundation (Project No 2000-067736.02), which are gratefully acknowledged. We thank Elias Samankassou, Stéphanie Védrine, and Niels Rameil for helping in the field and with the microfacies analysis, and for the discussions on the multiple aspects of carbonate sedimentology. We also thank the reviewers, Bernard Pittet and an anonymous person, for their constructive remarks.

\section{References}

Ainardi R (1977) Un paysage margino-littoral: le "Purbeckien" du Jura méridional. Bull Soc Geol Fr 2:257-264

Anderson FW (1985) Ostracod faunas in the Purbeck and Wealden of England. J Micropalaeontol 4:1-68

Anderson EJ (2004a) Facies patterns that define orbitally forced third, fourth-, and fifth-order sequences of sixth-order cycles and their relationship to ostracod faunicycles: the Purbeckian (Berriasian) of Dorset, England. In: D'Argenio B, Fischer AG, Premoli Silva I, Weissert H, Ferreri V (eds) Cyclostratigraphy: approaches and case histories. SEPM Spec Publ 81:245-260

Anderson EJ (2004b) The cyclic hierarchy of the "Purbeckian" Sierra del Pozo Section, Lower Cretaceous (Purbeckian), southern Spain. Sedimentology 51:455-477. doi:10.1111/j.1365-3091. 2004.00632.x

Anderson FW, Bazley RAB (1971) The Purbeck Beds of the Weald (England). Bull Geol Surv Great Br 34:9-43

Arnaud H (1988) Subsidence in certain domains of southeastern France during the Ligurian Tethys opening and spreading rates. Bull Soc Geol Fr 5:725-732

Berger A, Loutre MF, Dehant V (1989) Astronomical frequencies for pre-Quaternary palaeoclimate studies. Terra Nova 1:474-479. doi:10.1111/j.1365-3121.1989.tb00413.x

Blanc E (1996) Transect plate-forme-bassin dans les séries carbonatées du Berriasien supérieur et du Valanginien inférieur (domaines jurassien et nord-vocontien) Chronostratigraphie et transferts des sédiments. Géologie Alpine Mém. hs 25, Ph.D. Thesis. University of Grenoble, France, pp 312

Blanc E, Mojon P-O (1996) Un paléokarst du Crétacé basal (Berriasien moyen) dans le Jura suisse occidental (région de Bienne): corrélations avec les domaines boréal et téthysien. Cretaceous Res 17:403-418. doi:10.1006/cres.1996.0025

Burgess PM, Wright VP (2003) Numerical forward modeling of carbonate platform dynamics: an evaluation of complexity and completeness in carbonate strata. J Sediment Res 73:637-652. doi:10.1306/020503730637

Carozzi A (1948) Etude stratigraphique et micrographique du Purbeckien du Jura suisse. Ph.D. Thesis. University of Geneva, Switzerland, pp 175

Charollais J, Clavel B, Amato E, Escher A, Busnardo R, Steinhauser N, Macsotay O, Donze P (1983) Etude préliminaire de la faille du Vuache (Jura méridional). Bull Soc Vaud Sci Nat 76:217256

Clavel B, Charollais J, Busnardo R, Le Hégarat G (1986) Précisions stratigraphiques sur le Crétacé inférieur basal du Jura méridional. Eclogae Geol Helv 79:319-341

Cloyd KC, Demicco RV, Spencer RJ (1990) Tidal channel, levee, and crevasse-splay deposits from a Cambrian tidal channel system: a 
new mechanism to produce shallowing-upward sequences. J Sediment Petrol 60:73-83

Curnelle R, Dubois P (1986) Evolution mésozoïque des grands bassins sédimentaires français: bassins de Paris, d'Aquitaine et du Sud-Est. Bull Soc Geol Fr 4:529-546

D’Argenio B, Ferreri V, Weissert H, Amodio S, Buonocunto FP, Wissler L (2004) A multidisciplinary approach to global correlation and geochronology. The Cretaceous shallow-water carbonates of southern Apennines, Italy. In: D'Argenio B, Fischer AG, Premoli Silva I, Weissert H, Ferreri V (eds) Cyclostratigraphy: approaches and case histories. SEPM Spec Publ 81:103-122

Détraz H, Mojon P-O (1989) Evolution paléogéographique de la marge jurassienne de la Téthys du Tithonique-Portlandien au Valangien: corrélations biostratigraphique et séquentielle des faciès marins à continentaux. Eclogae Geol Helv 82:37-112

Détraz H, Steinhauser N (1988) Le bassin delphino-helvétique et sa marge jurassienne sous contrôle tectonique entre le Kimméridgien et le Valanginien. Eclogae Geol Helv 81:125-154

Drummond CN, Wilkinson BH (1993a) Carbonate cycle stacking patterns and hierarchies of orbitally forced eustatic sea level change. J Sediment Petrol 63:369-377

Drummond CN, Wilkinson BH (1993b) Aperiodic accumulation of cyclic peritidal carbonate. Geology 21:1023-1026. doi:10.1130/ 0091-7613(1993)021<1023:AAOCPC $>2.3 . \mathrm{CO} ; 2$

Embry AF (2002) Transgressive-regressive (T-R) sequence stratigraphy. 22nd Annual Gulf Coast Section SEPM Foundation Bob F. Perkins Reasearch Conference, pp 151-172

Flügel E (2004) Microfacies of carbonate rocks: analysis, interpretation and application. Springer, Berlin, p 976

Funk H (1985) Mesozoische Subsidenzgeschichte im Helvetischen Schelf der Ostschweiz. Eclogae Geol Helv 78:249-272

Ginsburg RN (1971) Landward movement of carbonate mud: new model for regressive cycles in carbonates. AAPG 55:340

Goldhammer RK, Dunn PA, Hardie LA (1990) Depositional cycles, composite sea-level changes, cycle stacking patterns, and the hierarchy of stratigraphic forcing: examples from Alpine Triassic platform carbonates. GSA Bull 102:535-562

Guillocheau F, Robin C, Allemand P, Bourquin S, Brault N, Dromart $\mathrm{G}$ et al (2000) Meso-Cenozoic geodynamic evolution of the Paris Basin: 3D stratigraphic constraints. Geodin Acta 13:189-246. doi:10.1016/S0985-3111(00)00118-2

Häfeli C (1966) Die Jura/Kreide-Grenzschichten im Bielerseegebiet (Kt. Bern). Eclogae Geol Helv 59:565-695

Hardenbol J, Thierry J, Farley MB, Jacquin T, de Graciansky P-C, Vail PR (1998) Mesozoic and Cenozoic sequence chronostratigraphic framework of European basins. In: de Graciansky P-C, Hardenbol J, Jacquin T, Vail PR (eds) Mesozoic and Cenozoic sequence stratigraphy of European basins, SEPM Spec Publ 60:chart

Hillgärtner H (1998) Discontinuity surfaces on a shallow-marine carbonate platform (Berriasian, Valanginian, France and Switzerland). J Sediment Res 68:1093-1108. doi:10.1306/D42689142B26-11D7-8648000102C1865D

Hillgärtner H (1999) The evolution of the French Jura platform during the Late Berriasian to Early Valanginian: controlling factors and timing. Ph.D. Thesis. University of Fribourg, Switzerland, GeoFocus 1, pp 203

Hillgärtner H, Strasser A (2003) Quantification of high-frequency sealevel fluctuations in shallow-water carbonates: an example from the Berriasian-Valanginian (French Jura). Palaeogeogr Palaeoclimatol Palaeoecol 200:43-63. doi:10.1016/S0031-0182(03)00444-9

Horne DJ (1995) A revised ostracod biostratigraphy for the PurbeckWealden of England. Cretaceous Res 16:639-663. doi:10.1006/ cres. 1995.1040

Horne DJ (2002) Ostracod biostratigraphy and palaeoecology of the Purbeck Limestone Group in southern England. In: Milner AR,
Batten DJ (eds) Life and environments in Purbeck times. Pal Association, London, pp 53-70

Immenhauser A, Scott RW (2002) An estimate of Albian sea-level amplitudes and its implication for the duration of stratigraphic hiatuses. Sediment Geol 152:19-28. doi:10.1016/S0037-0738 (02)00260-9

Jan du Chêne R, Busnardo R, Charollais J, Clavel B, Deconinck J-F, Emmanuel L et al (1993) Sequence-stratigraphic interpretation of Upper Tithonian-Berriasian reference sections in south-east France: a multidisciplinary approach. Bull Cent Rech Explor Prod Elf Aquitaine 17:151-183

Jimenez De Cisnero C, Vera JA (1993) Milankovitch cyclicity in Purbeck peritidal limestones of the Prebetic (Berriasian, southern Spain). Sedimentology 40:513-537. doi:10.1111/j.1365-3091. 1993.tb01348.x

Keen MC (1993) Ostracods as palaeoenvironmental indicators: examples from the Tertiary and Early Cretaceous. In: Jenkins DG (ed) Applied micropaleontology, Kluwer Academic Press, Dordrecht, pp 41-67

Kendall GSC, Schlager W (1981) Carbonates and relative changes in sea level. Mar Geol 44:181-212. doi:10.1016/0025-3227(81) 90118-3

Le Hégarat G (1973) Le Berriasien du Sud-Est de la France. Doc Lab Sci Geol Fac Lyon 43:576

Lehmann C, Osleger DA, Montañez IP (1998) Controls on cyclostratigraphy of Lower Cretaceous carbonates and evaporites, Cupido and Coahuila platforms, Northeastern Mexico. J Sediment Res 68:1109-1130

Lehrmann DJ, Goldhammer RK (1999) Secular variation in parasequence and facies stacking patterns of platform carbonates: a guide to application of stacking-pattern analysis in strata of diverse ages and settings. In: Harris PM, Saller AH, Simo JA (eds) Advances in carbonate sequence stratigraphy: application to reservoirs, outcrops and models. SEPM Spec Publ 63:187-225

Loup B (1992) Mesozoic subsidence and stretching models of the lithosphere in Switzerland (Jura, Swiss Plateau and Helvetic realm). Eclogae Geol Helv 85:541-572

Martín-Closas C, Serra-Kiel J (1991) Evolutionary patterns of Clavatoraceae (Charophyta) in the Mesogean basins analyzed according to environmental change during Malm and Lower Cretaceous. Hist Biol 5:291-307

Miall AD, Miall CE (2004) Empiricism and model-building in stratigraphy: around the hermeneutic circle in the pursuit of stratigraphic correlation. Stratigraphy 1:27-46

Mojon P-O (2002) Les formations mésozoïques à charophytes (Jurassique moyen- Crétacé inférieur) de la marge téthysienne nord-occidentale (Sud-Est de la France, Suisse occidentale, Nord-est de l'Espagne) sédimentologie, micropaléontologie, biostratigraphie. Ph.D. Thesis. University of Grenoble, France, pp 386

Mojon P-O, Strasser A (1987) Microfaciès, sédimentologie et micropaléontologie du Purbeckien de Bienne (Jura suisse occidental). Eclogae Geol Helv 80:37-58

Osleger D (1991) Subtidal carbonate cycles: implications for allocyclic vs. autocyclic controls. Geology 19:917-920. doi:10. 1130/0091-7613(1991)019<0917:SCCIFA > 2.3.CO;2

Osleger DA, Read JF (1991) Relation of eustacy to stacking patterns of meter-scale carbonate cycles, Late Cambrian, U.S.A. J Sediment Res 61:1225-1252

Pasquier J-B (1995) Sédimentologie, stratigraphie séquentielle et cyclostratigraphie de la marge nord-téthysienne au Berriasien en Suisse occidentale (Jura, Helvétique et Ultrahelvétique; comparaison avec les séries de bassin des domaines Vocontien et Subbriançonnais). Ph.D. Thesis. University of Fribourg, Switzerland, pp 274 
Pasquier J-B, Strasser A (1997) Platform-to-basin correlation by highresolution sequence stratigraphy and cyclostratigraphy (Berriasian, Switzerland and France). Sedimentology 44:1071-1092. doi:10.1046/j.1365-3091.1997.d01-62.x

Persoz F, Remane J (1976) Minéralogie et géochimie des formations à la limite Jurassique-Crétacé dans le Jura et le Bassin vocontien. Eclogae Geol Helv 69:1-38

Platt NH (1989) Lacustrine carbonates and pedogenesis: sedimentology and origin of palustrine deposits from the Early Cretaceous Rupelo Formation, W Cameros Basin, N Spain. Sedimentology 36:665-684. doi:10.1111/j.1365-3091.1989.tb02092.x

Pratt BR, James NP (1986) The St George Group (Lower Ordovician) of western Newfoundland: tidal flat island model for carbonate sedimentation in shallow epeiric seas. Sedimentology 33:313343. doi:10.1111/j.1365-3091.1986.tb00540.x

Pratt BR, James NP (1992) Peritidal carbonates. In: Walker RG, James NP (eds) Facies models, response to sea-level change. Geol Assoc, Canada, pp 303-322

Rameil N (2005) Carbonate sedimentology, sequence stratigraphy, and cyclostratigraphy of the Tithonian in the Swiss and French Jura mountains: a high-resolution record in sea level and climate. Ph.D. Thesis. University of Fribourg, Switzerland, GeoFocus 13, pp 246

Raspini A (2001) Stacking pattern of cyclic carbonate platform strata: Lower Cretaceous of southern Appennines, Italy. J Geol Soc London 158:353-366

Read JF, Grotzinger JP, Bova JA, Koerschner WF (1986) Models for generation of carbonate cycles. Geology 14:107-110. doi:10.1130/0091-7613(1986)14<107:MFGOCC >2.0.CO;2

Riveline J, Berger J-P, Feist M, Martín-Closas C, Schudack ME, Soulié-Märsche I (1996) European Mesozoic-Cenozoic charophyte biozonation. Bull Soc Geol Fr 167:453-468

Sadler PM (1994) The expected duration of upward-shallowing peritidal carbonate cycles and their terminal hiatuses. Geol Soc Am Bull 106:791-802. doi:10.1130/0016-7606(1994)106<0791: TEDOUS $>2.3 . \mathrm{CO} ; 2$

Sandulli R, Raspini A (2004) Regional to global correlation of lower Cretaceous (Hauterivian-Barremian) shallow-water carbonates of the southern Apennines (Italy) and Dinarides (Montenegro), southern Tethyan Margin. Sediment Geol 165:117-153. doi: 10.1016/j.sedgeo.2003.11.014

Satterley AK (1996) The interpretation of cyclic successions of the Middle and Upper Triassic of the northern and southern Alps. Earth Sci Rev 40:181-207. doi:10.1016/0012-8252(95)00063-1

Schlager W (2005) Carbonate sedimentology and sequence stratigraphy. SEPM Conc Sedimentol Paleontol 8:200

Schwarzacher W (1993) Cyclostratigraphy and the Milankovitch theory. Elsevier, Amsterdam, p 225

Steinhauser N, Charollais J (1971) Observations nouvelles et réflexions sur la stratigraphie du "Valanginien" de la région neuchâteloise et ses rapports avec le Jura méridional. Geobios 4:1-59. doi:10.1016/S0016-6995(71)80006-2

Steinhauser N, Lombard A (1969) Définition de nouvelles unités lithostratigraphiques dans le Crétacé inférieur du Jura méridional (France). C R Soc Phys Hist nat Genève 4:100-113

Strasser A (1987) Detaillierte Sequenzstratigraphie und ihre Anwendung: Beispiel aus dem Purbeck des schweizerischen und französischen Jura. Facies 17:237-244. doi:10.1007/ BF02536788

Strasser A (1988) Shallowing-upward sequences in Purbeckian peritidal carbonates (lowermost Cretaceous, Swiss and French Jura Mountains). Sedimentology 35:369-383. doi:10.1111/j. 1365-3091.1988.tb00992.x

Strasser A (1991) Lagoonal-peritidal sequences in carbonate environments: autocyclic and allocyclic processes. In: Einsele G, Ricken W, Seilacher A (eds) Cycles and events in stratigraphy. Springer, Berlin, pp 709-721
Strasser A (1994) Milankovitch cyclicity and high-resolution sequence stratigraphy in lagoonal-peritidal carbonates (Upper Tithonian-Lower Berriasian, French Jura Mountains). In: De Boer PL, Smith DG (eds) Orbital forcing and cyclic sequences. IAS Spec Publ 19:285-301

Strasser A, Hillgärtner H (1998) High-frequency sea-level fluctuations recorded on a shallow carbonate platform (Berriasian and Lower Valanginian of Mount Salève, French Jura). Eclogae Geol Helv 91:375-390

Strasser A, Samankassou E (2003) Carbonate sedimentation rates today and in the past: Holocene of Florida Bay, Bahamas, and Bermuda vs. Upper Jurassic and Lower Cretaceous of the Jura Mountains (Switzerland and France). Geol Croat 56:1-18

Strasser A, Pittet B, Hillgärtner H, Pasquier J-B (1999) Depositional sequences in shallow carbonate-dominated sedimentary systems: concepts for a high-resolution analysis. Sediment Geol 128:201221. doi:10.1016/S0037-0738(99)00070-6

Strasser A, Hillgärtner H, Pasquier J-B (2004) Cyclostratigraphic timing of sedimentary processes: an example from the Berriasian of the Swiss and French Jura Mountains. In: D'Argenio B, Fischer AG, Premoli Silva I, Weissert H, Ferreri V (eds) Cyclostratigraphy: approaches and case histories. SEPM Spec Publ 81:137-151

Strohmenger C, Strasser A (1993) Eustatic controls on the depositional evolution of Upper Tithonian and Berriasian deep-water carbonates (Vocontian Trough, SE France). Bull Cent Rech Explor Prod Elf Aquitaine 17:183-203

Thierry J, Barrier E (2000) Early Tithonian (141-139 Ma). In: Dercourt J, Gaetani M, Vrielynck B, Barrier E, Biju-Duval B, Brunet MF, Cadet J-P, Crasquin S, Sandulescu M (eds) PeriTethys atlas. CCGM/CGMW, Paris, pp 99-110

Tipper JC (1997) Modeling carbonate platform sedimentation-lag comes naturally. Geology 25:495-498. doi:10.1130/00917613(1997)025<0495:MCPSLC > 2.3.CO;2

Tresch J (2007) History of a Middle Berriasian transgression (Switzerland, France, and southern England). Ph.D. Thesis. University of Fribourg, Switzerland, GeoFocus 16, pp 271

Trümpy R (1980) Geology of Switzerland-a guide-book. Wepf \& Co, Basel, pp 7-24

Védrine S, Strasser A, Hug W (2007) Oncoid growth and distribution controlled by sea-level fluctuations and climate (Late Oxfordian, Swiss Jura Mountains). Facies 53:535-555. doi:10.1007/s10347007-0114-4

Waehry A (1989) Faciès et séquences de dépôt dans la formation de Pierre-Châtel (Berriasien moyen, Jura méridional/France). Unpubl diploma thesis. University of Geneva, Switzerland, pp 75

Wildi W, Funk H, Loup B, Amato E, Huggenberger P (1989) Mesozoic subsidence history of the European marginal shelves of the alpine Tethys (Helvetic realm, Swiss Plateau and Jura). Eclogae Geol Helv 82:817-840

Wilkinson BH, Diedrich NW, Drummond CN (1996) Facies successions in peritidal carbonate sequences. J Sediment Res 66:10651078

Wilkinson BH, Drummond CN, Rothman ED, Diedrich NW (1997) Stratal order in peritidal carbonate sequences. J Sediment Res 67:1068-1082

Wright VP (1994) Paleosols in shallow marine carbonate sequences. Earth Sci Rev 35:367-395. doi:10.1016/0012-8252(94)90002-7

Wright VP, Burgess PM (2005) The carbonate factory continuum, facies mosaics and microfacies: an appraisal of some of the key concepts underpinning carbonate sedimentology. Facies 51:1723. doi:10.1007/s10347-005-0049-6

Ziegler PA (1988) Evolution of the Arctic-North Atlantic and the western Tethys. AAPG Mem 43:198 